\title{
FEDERAL REGULATION OF REAL ESTATE INVESTMENT TRUSTS: A LEGISLATIVE PROPOSAL
}

\author{
WiLliam L. MARTIN, II $\dagger$
}

\section{INTRODUCTION}

The real estate investment trust ("REIT") is an unincorporated association or business trust managed by one or more trustees that invests funds of a number of investors in real estate, mortgages secured by real estate, or some combination thereof. ${ }^{1}$ Although the business trust as an organizational form has existed at least since the nineteenth century, ${ }^{2}$ it was not until after 1960, when Congress passed legislation exempting qualified REITS from federal taxation, ${ }^{3}$ that the REIT gained widespread popularity as a real estate investment vehicle.

† Division of Enforcement, United States Securities and Exchange Commission. J.D., Georgetown University Law Center, 1974. Member, Pennsylvania Bar.

The Commission as a matter of policy disclaims responsibility for the private publications of its employees. The views expressed herein are solely those of the author and do not necessarily reflect those of the Commission or any other members of its staff.

1 REITs are typically classified into three categories, depending upon the composition of their portfolios. Equity REITs invest directly in real estate interests, typically income-producing properties such as apartments or shopping centers. Mortgage REITs invest in mortgages secured in whole or in part by interests in real estate. Hybrid REITs purchase both equity interests and mortgages. Mortgage trusts are sometimes further classified as short-term trusts-those that typically invest in short-term construction and development ("C \& D") mortgages-and long-term trusts--those that invest in mortgages with long-term maturities typically secured by completed real estate projects. See generally National Ass'n of Real Estate INVESTMENT TRUSTS, REIT FACTBOoK 6-10 (1977) [hereinafter cited as REIT FACTBOOK, 1977].

2 Most REITs are organized as Massachusetts business trusts, a business form that appears to have received judicial recognition in that jurisdiction as early as 1827 . See State Street Trust Co. v. Hall, 311 Mass. 299, 304, 41 N.E.2d 30, 34 (1942). Other jurisdictions also appear to have recognized the business trust as a form of commercial enterprise at an early date. See Annot., 156 A.L.R. 13, 28-30 \& n.16 (1945) and cases cited therein.

3 I.R.C. $\$ \$ 856-858$. To qualify for exemption from state and federal corporate income taxes under the foregoing sections, a REIT must meet a number of tests regarding types of investments, sources of income, and distributions to shareholders. The principal requirements are as follows:

(1) At least 90 percent of the REIT's gross income must be distributed to shareholders (increasing to 95 percent in 1980);

(2) At least 75 percent of the REIT's assets must consist of interests in real estate, loans secured by interests in real estate, shares in other REITs, or cash and cash equivalents;

(3) At least 75 percent of the REIT's gross income must be real estate-related, including rents and interest; 
In passing the original legislation according qualified REITs tax-exempt status, Congress' principal concern was to create parity of tax treatment between REITs and regulated investment companies, or so-called mutual funds. Since 1936, qualified investment companies had been permitted to "pass through" earnings to shareholders without incurring the normal income tax levied against corporations and nonqualified investment companies. ${ }^{4}$ The exemption was designed to promote investment by allowing small investors to secure expert investment advice and the economies of scale associated with large transactions without burdening such an investment vehicle with the customary double taxation imposed on corporate dividends. ${ }^{5}$ In exempting qualified REITs from normal income taxation, Congress in 1960 sought to provide similar incentives for small investors in real estate. ${ }^{6}$

In seeking to ensure tax parity between REITs and investment companies, however, Congress took no steps to assure regulatory parity between the two types of enterprises. Since 1940, investment companies had been subject to a comprehensive federal regulatory scheme designed to protect investors from the panoply of abuses found to exist in such companies. This regulatory scheme was embodied in the Investment Company Act of 1940 ("Investment Company Act"' ${ }^{7}$ and its companion act, the Investment Advisers Act of 1940 ("Investment Advisers Act"). ${ }^{8}$ Both acts sought, among other things, to ensure that investors who entrusted their funds to investment companies would not be subject to undue risk due to imprudent financial structures, self-dealing, and conflicts of interest generated by those charged with the management of fund assets. ${ }^{\circ}$

(4) The REIT may not hold or develop real estate for sale to customers in the ordinary course of business; and

(5) Beneficial ownership of the REIT must be held by no fewer than 100 shareholders for at least 335 days of a tax year, and five or fewer persons may not own more than half of the outstanding stock during the last half of the taxable year.

See REIT FACTBOOK, 1977, supra note 1, at 34 .

4 See J. Mertens, Law of Federal Income Taxation $\$ 41.02$ (1976).

5 See H.R. ReP. No. 1337, 83d Cong., 2d Sess. 73, reprinted in [1954] U.S. Cone Cong. \& AD. News 4099; S. Rep. No. 1622, 83d Cong., 2d Sess. 101, reprinted in [1954] U.S. CODE Cong. \& AD. News 4734 (legislative history of I954 Internal Revenue Code).

${ }^{6}$ H.R. REP. No. 2020, 86th Cong., 2d Sess. 3 (1960); H.R. Rep. No. 2842, 84th Cong., $2 d$ Sess. 4 (1956); S. Rep. No. 2797, 84th Cong., 2d Sess. 2 (1956).

7 Ch. 686, 54 Stat. 789 (1940) (Currently codified at 15 U.S.C. $\$ \$ 80 \mathrm{a}-1$ to 80a-52 (1976)).

s Id. 847 (currently codified at 15 U.S.C. $\$ \$ 80 \mathrm{~b}-1$ to $80 \mathrm{~b}-21$ (1976)).

9 For a succinct description of the background and regulatory objectives of the Investment Company Act and the Investment Advisers Act, see 1 L. Loss, Srcuriimes Regulation 144-55 (1961). 
By contrast, REITs were not in 1960, nor have they been at any time since then, subject to comparable regulatory safeguards. Section 3(c)(6) of the Investment Company Act ${ }^{10}$ exempted from the provisions of the Act companies investing in real estate or mortgages secured by real estate. ${ }^{11}$ The Securities and Exchange Commission has interpreted this provision to apply to most REITs. ${ }^{12}$ Various states have sought, through blue sky regulations, to impose restrictions on REITs the shares of which are offered for sale within the state; these regulations, however, have proved inadequate and have not been broadly applied. ${ }^{13}$

This difference in regulatory treatment is anomalous given the fact that REITs and investment companies, by virtue of their management structures and objectives, are highly similar. Hence, both enterprises represent the pooled capital of a number of small investors; both seek to secure economies of scale for individual investors by aggregating and managing large amounts of capital; and, most significantly, both typically are managed, pursuant to

10 Ch. 686, $\$ 3(c)(6), 54$ Stat. $789,798-99$ (1940) (current version at 15 U.S.C. $\$ 80 \mathrm{a}-3(\mathrm{c})(5)$ (C) (1976)). Pursuant to the 1970 amendments to the Investment Company Act, $\S 3(\mathrm{c})(6)$ became $\$ 3(\mathrm{c})(5)(\mathrm{C})$. Pub. L. No. 91-547, $\S 3$, 84 Stat. 1413 (amending 15 U.S.C. $\$ 80 a-3(c)(6)$ (1964)).

11 Section 3(c)(6) of the Investment Company Act of 1940 excluded from the definition of an investment company "[a]ny person who is not engaged in the business of issuing face-amount certificates of the installment type or periodic payment plan certificates, and who is primarily engaged in .... (C) purchasing or otherwise acquiring mortgages and other liens on or interests in real estate." Investment Company Act of 1940, ch. 686, \$3(c)(6), 54 Stat. 789, 798-99 (1940) (current version at 15 U.S.C. $\$ 80 \mathrm{a}-3(\mathrm{c})(5)(\mathrm{C})(1970))$.

The legislative rationale for the inclusion of $\S 3(\mathrm{c})(6)$ is not altogether clear. The Investment Company Act was, in large measure, a response to the findings of the massive Study of Investment Trusts and Investment Companies completed by the Securities and Exchange Commission and forwarded to Congress in 1939. Although the study included a comprehensive survey of almost 1200 investment companies then in existence, it appears that only one company was included that engaged in the acquisition of real estate-interests-Investors Syndicate, Inc., a face amount certificate company. A reading of the hearings and conference reports resulting from the ensuing congressional consideration of the proposed Investment Company Act reveals virtually no discussion of the propriety of the exclusion of real estate and mortgage companies, although the legislative history of subsequent amendments to the Act would seem to indicate that these companies were excluded simply because they do not fall within the generally-understood concept of investment companies "investing in stocks and bonds of corporate issuers." H.R. REP. No. 1382, 91st Cong., 2d Sess. 17 (1970).

12 Securities \& Exchange Comm'n, Securities Act Release No. 4298 (Nov. 18, 1960):

[I]n determining the applicability of the exception contained in Section $3(c)(6)(C)$, the character of the trust's assets must be considered. In this respect, no question would be raised where a real estate investment trust invested exclusively in fee interests in real estate or mortgages or liens secured by real estate.

Id.

13 See notes 56-62 infra \& accompanying text. 
advisory contracts, by external investment managers who are responsible, among other things, for investment recommendations, financing decisions, and administration of the day-to-day affairs of the enterprise. ${ }^{14}$

The regulatory anomaly has been further heightened by the high risk investment practices of REITs and their consequently disastrous economic performance-both important factors in prompting the regulatory legislation originally directed at investment companies. Between 1968 and 1973, the annual number of REIT offerings increased from fourteen to sixty-five ${ }^{15}$ and total REIT assets increased from $\$ 1.03$ billion to over $\$ 20$ billion. ${ }^{16}$ Much of the growth during this period was financed by massive bank and commercial paper borrowing by REITs, ${ }^{17}$ the proceeds of which were in turn loaned to unseasoned developers to finance unproven projects involving high degrees of risk. ${ }^{18}$ When, in late 1973 and 1974, the real estate sector began to deteriorate, the effects of these practices proved disastrous. Within the space of two years, REIT assets decreased from almost $\$ 21$ billion to $\$ 16.5$ billion, ${ }^{19}$ total reserves for loan losses increased from $\$ 780$ million to $\$ 2.3$ billion, and the aggregate stock prices of all REITs fell by more than twothirds. ${ }^{20}$ Three of the ten largest REITs in 1974 subsequently filed for bankruptcy. ${ }^{21}$

14 REIT FActBoox, 1977, supra note 1, at 12-14.

$15 \mathrm{Id} .27$.

${ }^{16}$ Id. 28.

17 In 1968, total borrowings by REITs from these sources stood at $\$ 90$ million; in 1973 , borrowings had increased to over $\$ 10$ billion. Id.

18 For an analysis of the principal high risk lending practices utilized by mortgage REITs during this period of rapid expansion, see Drexel Burnham \& Co., Bank Loans to REITs: Problems and Prospects 29 (1975), reprinted in Real Estate Investment Trusts: Hearings on S. 2721 before the Senate Comm. on Banking, Housing, and Utban Affairs, 94th Cong., 2d Sess. 297 (1976) [hereinafter cited as REIT Hearings]; Ostema, Back to Basics in Real Estate-Trusts Tried Innovations That Served No One Well, N.Y. Times, July 14, 1974, § F, at 12, col. 1.

19 REIT FACTBOoK, 1977, supra note 1, at 28.

20 Id. 21 (National Ass'n of Real Estate Investment Trusts (NAREIT) Stock Price Index, Jan. 1974-Dec. 1975).

21 Continental Mortgage Investors; First Mortgage Investors; Great American Mortgage Investors.

Although a detailed analysis of the rise and fall of the REIT industry during the past dozen or so years is beyond the scope of this Article, REIT literature contains a large number of articles on the subject. See, e.g., Benger, Banks' Dismay Over REITs, N.Y. Times, Sept. 29, 1974, \$ F, at 2, col. 1; Ostema supra note 18; Robertson, How the Bankers Got Trapped in the REIT Disaster, FonTunE, March 1975, at 113; New Lows for the Once Mighty REITs, Bus. WeEs, April 20, 1974, at 82; REITs Face Shakeout as Investments Sour, Cash Sources Dry Up, Wall St. J.; Jan. 21,1974 , at 1 , col. 1 . 
It is the essential similarity of the REIT to the regulated investment company and the need to evaluate federal regulation of the REIT along lines similar to those now imposed on regulated investment companies that is the focus of this Article. The Article will examine three areas of regulatory concern common to REITs and regulated investment companies: (1) conflicts of interest involving transactions between such companies on the one hand and their investment advisers and affiliates of such advisers on the other; (2) negotiation of advisory contracts between such companies and their investment advisers; and (3) regulation of excessive risk taking, principally in the area of debt leverage. In each of these areas, the Article will determine whether the Investment Company Act embodies a regulatory concern that also applies to the structure and operation of REITs, and, if so, whether existing federal and state laws adequately address that concern. The Article will further consider the pros and cons of the regulatory approaches utilized by the Investment Company Act in these areas and will conclude with a recommendation for a specific legislative approach in each. ${ }^{22}$

\section{CONFLicts of INTEREST}

\section{A. Background}

The Investment Company Act of 1940 ("Investment Company Act") ${ }^{23}$ was in large measure a legislative response to a widespread variety of conflicts of interest and resulting abuses that had characterized the management and operation of the mutual fund industry; ${ }^{24}$ these abuses were attributable in large part to the unique

22 The similarity between REITs and regulated investment companies and the need to regulate REITs on a basis comparable to that under which invesiment companies are regulated has been suggested, though not fully explored, by several commentators. See, e.g., Kraut, REITs as Investment Companies-Advising the Independent Trustee of Real Estate Investment Trusts, 3 ReaL Estate Issues 43 (1978); Lynn, Real Estate Investment Trusts: Problems and Prospects, 31 FORDHAN L. Rev. 73, 103-08 (1962); Rosenblat \& Lybecker, Some Thoughts on the Federal Securities Laws Regulating External Investment Management Arrangements and the ALI Federal Securities Code Project, 124 U. PA. L. REv. 587, 681-85 (1976). $23 \mathrm{Ch} .686,54$ Stat. 789 (1940) (currently codified at 15 U.S.C. $\$ \$ 80 \mathrm{a}-1$ to 80a-52 (1976).

24 Section 1 (b) of the Investment Company Act itself recites this conclusion:

(b) Upon the basis of facts disclosed by the record and reports of the Securities and Exchange Commission . . i it is hereby declared that the national public interest and the interest of investors are adversely affected

(2) when investment companies are organized, operated, managed, or their portfolio securities are selected, in the interest of directors, officers, investment advisers, depositors, or other affliated persons thereof, in the interest of underwriters, brokers, or dealers, in the interest of special classes of their security holders, or in the interest of other investment companies 
managerial structure of most mutual funds. Unlike the typical corporation ${ }^{25}$ a mutual fund consists almost solely of a portfolio of liquid securities in which fund shareholders hold undivided fractional interests. The management of the portfolio and the fund's business affairs typically is the responsibility of the investment adviser, an independent entity that is compensated for its services by a fee that is usually based upon a percentage of the size of the fund's portfolio. Although the interests of the fund and its adviser are to some extent congruent, those interests may differ substantially in important areas, including fund growth and size, capitalization and leverage, portfolio transactions, management fees, and sales charges. $^{28}$ It was these types of conflicts, among others, that Congress sought to minimize in passing the Investment Company Act. ${ }^{27}$

The management structure of the typical REIT is similar to that of the mutual fund. The REIT itself is a mere shell, with a portfolio consisting of real estate equity interests, mortgages, or some combination thereof. ${ }^{28}$ Management of the trust's business affairs is typically vested in an external management company, which, for compensation, performs duties that typically include location and underwriting of real estate investments, periodic analysis of and

or persons engaged in other lines of business, rather than in the interest of

all classes of such companies' security holders . . . .

15 U.S.C. $\$ 80 \mathrm{a}-1(\mathrm{~b})(2)(1976)$.

The legislative history of the Investment Company Act, including the SEC's Investment Trust Study and the congressional hearings on the proposed bills, contain lengthy litanies describing instances of fund mismanagement by officers, directors, advisers, and affiliates whose interests were at odds with those of the funds with which they dealt. Hearings on S. 3580 before a Subcomm. of the Senate Comm. on Banking and Currency, 76th Cong., 3d Sess. (1940) [hereinafter cited as Investment Company Act Hearings]; Secunuties \& Exchange Commision, Investment Trusts and INvestment Companies (1939) (in particular part III) [hereinafter cited as Investment Trust STudy]. See generally L. Loss, supra note 9 , at $149-50$.

25 The management of the typical corporation is entrusted to officers and directors who are paid employees of the corporation itself and who often have a substantial equity interest in the company. Presumably, the interests of management and shareholders in profit maximization are coextensive, thus minimizing actual and potential conflicts of interest between the two groups. Tannenbaum v. Zeller, 552 F.2d 402, 405 (2d Cir.), cert. denied sub nom. F. Eberstadt \& Co. v. Tannenbaum, 434 U.S. 934 (1977).

28 For a particularly good analysis of the conflicts of interest that characterize mutual fund management, see Note, The Relationship Between the Investment Adviser and the Mutual Fund: Too Close for Comfort, 45 FordhaM L. REv. 183 (1976). See also Mundheim, Some Thoughts on the Duties and Responsibilities of Unaffiliated Directors of Mutual Funds, 115 U. PA. L. Rev. 1058, 1059-60 (1967).

27 Tannenbaum v. Zeller, 552 F.2d at 406. See also Rosenfeld v. Black, 445 F.2d 1337 (2d Cir. 1971), cert. dismissed sub nom. Lazard Frères \& Co. v. Rosenfeld, 409 U.S. 802 (1972).

28 See note 1 supra. 
recommendations with respect to portfolio holdings, and location and maintenance of credit relationships with lending institutions. ${ }^{29}$

As a result of this external management structure, many of the same kinds of conflicts that are endemic to the investment company and that Congress sought to regulate in the Investment Company Act are present in the REIT. Hence, because the investment adviser's compensation is frequently based on fund size, ${ }^{30}$ the adviser has an incentive to promote rapid growth when in fact such growth may not be in the trust's best interest and may be achieved only by underwriting investments of marginal quality. In addition, if the adviser or any of its affiliates has the capability to provide services that the REIT may require, the adviser's loyalties in recommending its services or those of its affiliates vis-á-vis alternative sources similarly may be divided. ${ }^{31}$ Finally, though not least significantly, when a REIT adviser is a subsidiary or affiliate of an institution engaged in lending and real estate investment in areas in which the REIT also invests, the adviser institution faces a substantial conflict of interest in deciding whether to recommend favorable investments to the REIT or to acquire them for its own account. ${ }^{32}$

The foregoing conflicts are not merely hypothetical. Although there have been no studies of conflicts of interest and concomitant abuses in REITs similar to the Securities and Exchange Commission's ("SEC," "Commission") Investment Trust Study, ${ }^{33}$ available data suggest that actual and potential conflicts of interest are not uncommon in REITs. Hence, in four civil injunctive actions by

29 Although it is not necessary for REITs to have external management to qualify for pass-through treatment under $\$ \$ 856-858$ of the Internal Revenue Code, most REITs still maintain this type of management arrangement. Hence, as of the end of 1977, 150 REITs still utilized external management companies (a decrease from approximately 175 two years earlier), whereas a total of 40 trusts were self-administered. REIT FACTBOOK, 1977, supra note 1 , at $13,39$.

30 See notes 157-59 infra \& accompanying text.

31 This is particularly true of REITs sponsored by commercial banks. As one commentator observes:

The bank, through the advisory subsidiary, may direct the trust to borrow funds from the bank when the REIT may have less expensive financing options available. The bank may sell its trust various banking services, such as those of a registrar or stock transfer agent, at higher prices than are available elsewhere. If the REIT deposits are held by the bank, then the advisor may maintain excessively high cash balances to the benefit of the bank and to the detriment of the REIT. As part of the tie-in business strategy, the bank may require that parties who do business with the REIT must maintain deposits with the bank.

REIT HEARINGs, supra note 18, at 47 (statement of B. Neuberger).

32 Id. 46. For two excellent discussions of conflicts of interest in REIT management generally, see id. 96-107 (statement of $\mathrm{R}$. Schotland) and Duval, "Conflict of Interest Problems in the Management of REITs, 3 REAL EsTATE L.J. 23 (1974). 33 See note 24 supra. 
the SEG involving REITs, ${ }^{34}$ the Commission has alleged various abuses by REIT advisory companies, including investments in marginal loans for purposes of increasing advisory fees, concealment of performance data on trust investments for purposes of maintaining the level of the advisory fee, undisclosed maladministration of trust loans by investment advisers, investments in assets not authorized by the applicable declaration of trust, and phony transactions with affiliated borrowers to increase the apparent fair market value of REIT properties. In the only one of the four cases that has been the subject of litigated findings of fact it was found, among other things, that the defendant REIT, although ostensibly directed by an independent outside adviser, was in reality operated by a "cabinet" of individuals who also operated a number of other affiliated real estate companies. The court further found that certain of these individuals had structured a series of sham real estate transactions designed to conceal losses from the REIT's shareholders and to overstate earnings through generation of fictitious profits. ${ }^{35}$

Examination of prospectuses and periodic reports filed with the SEC by publicly-held REITs further indicates that REITs and their investment advisers are in habitual positions of conflicting interests. In 1977, all of the ten largest externally-managed REITs were sponsored or advised by financial institutions (or subsidiaries thereof) that were engaged in real estate activities parallel to those of the REIT and that were acknowledged to be in competition with the REIT for investment opportunities. ${ }^{36}$ More significantly, each of the ten REITs disclosed the existence of trans-

34 SEC v. Citizens \& Southern Realty Investors, Civ. No. 78-0711 (D.D.C., filed April 21, 1978); SEC v. Continental Advisers, Civ. No. 78-0066 (D.D.C., filed Jan. 16, 1978); SEC v. First Mortgage Investors, Civ. No. 75-1850-CIV-JE (S.D. Fla., filed Sept. 5, 1975); SEC v. Standard Life Corp., Civ. No. 75-0052-E (W.D. Okla., filed July 2, 1975).

35 SEC v. First Mortgage Investors, Civ. No. 75-1850-CIV-JB (S.D. Fla., filed July 17, 1978).

36 See Appendix A. A typical disclosure of such conflict reads as follows:

Possible Conflicts of Interest. Real estate investment activities of [the Adviser] will parallel those of the Trust in many types of its investments, and therefore to a certain extent [the Adviser] will be engaged in competition with the Trust for available investment opportunities. While [the Adviser] has agreed to use its best efforts to present to the Trust a continuing and suitable investment program consistent with the investment policies and objectives of the Trust, [the Adviser] is not required to present to the Trust any particular investment opportunities which come to [the Adviser], even if such opportunities are such that, if presented to the Trust, could be taken by the Trust.

MONY Mortgage Investors, Prospectus dated April 14, 1970, at 3-4. See also Cates \& Harwell, Banks' Big Stakes in REIT Field, BANKER's MonTEn, August 15,1970 , at 19,45 . 
actions between the REIT and the adviser or affiliates of the adviser involving possibly substantial conflicts. These transactions included loans in which the REIT and the adviser had a joint interest, ${ }^{37}$ direct loans by the REIT to affiliated persons, ${ }^{38}$ purchases of real property by the REIT from affiliated persons, ${ }^{39}$ service contracts between the REIT and business entities owned in whole or in part by the REIT's investment adviser or its affiliates, ${ }^{40}$ and purchases of REIT portfolio assets by investment advisers or their affiliates in return for reductions of outstanding indebtedness to the adviser. ${ }^{41}$

\section{B. Existing Safeguards}

Superficially, the same types of legislative concerns that apply to the external management structure of the mutual fund and resulting conflicts of interest have equally valid application to the REIT. Whether those concerns justify federal regulation, how-

37 See Appendix A. Of the 10 REITs surveyed, all but one disclosed joint loans in which the Trust and the Adviser (or the Adviser's parent) participated. In most cases, the REIT's participation involved significant loan balances, including $\$ 95.4$ million in participations by MONY Mortgage Investors, $\$ 119.7$ million by Connecticut General Mortgage and Realty Investments, and $\$ 409$ million by Equitable Life Mortgage and Realty Investors. Id.

38 See Appendix A. Of the 10 largest REITs surveyed, four disclosed transactions involving one or more of the following: (1) loans to entities in which trustees of the trust or directors of the adviser had a direct interest; (2) issuance of loan commitments on properties in which affiliates of the advisory company had an interest; and (3) loans to subsidiaries of the adviser or joint ventures in which wholly-owned subsidiaries of the adviser had an interest.

39 One of the 10 REITs surveyed disclosed a purchase of developed property from a wholly-owned subsidiary of the adviser's parent. Appendix A (Connecticut General Mortgage and Realty Investments).

40 See Appendix B. Of the 10 largest externally-managed REITs in 1977, five disclosed the amounts of compensation paid to the adviser or its affiliates for services not covered by the advisory contract. These typically included fees for servicing long-term mortgages received by the Trust, although fees were also received for other services, including stock transfers, auditing, commercial paper endorsement, property management, underwriting of securities offerings, and registrar services. In some cases the additional fees were small, although in others they ran into several million dollars. Id.

41 Three of the largest bank-sponsored REITs have disclosed significant purchases of assets by the bank-sponsors from the REIT. See Chase Manhattan Mortgage and Realty Investors, Registration Statement on Form S-1 dated May 27, 1977, at 50; Citizens and Southern Realty Investors, Registration Statement on Form S-11 dated April 28, 1978, at 73; Continental Illinois Realty, Annual Report on Form 10-K dated June 23, 1977, at 45. For a discussion of REIT asset swaps generally, see Nicholson, Problem Assets Still Plague Trusts Despite Swaps, 19 Nat'z Rear Estate Investor 21 (1977); Nicholson, Properties Selling for Inflated Prices in Asset Swaps, 18 NAT'L Real Estate Investor 18 (1976); Schorr \& Meyer, Realty Trusts Raise Cash, Repay Bankers by Giving Up Assets, Wall St. J., Jan. 5, 1976, at 1, col. 6; Troubled REITs Swap Assets for Cash, Bus. WEEK, July 21, 1975, at 68. 
ever, depends upon the adequacy of existing mechanisms designed to insulate the REIT from possible abuses endemic to such conflicts. Broadly speaking, these mechanisms may be said to fall into three categories: (a) restrictions imposed by the REIT itself; (b) restrictions imposed by state law; and (c) restrictions imposed by federal law.

\section{Self-Imposed Restrictions}

Most REITs operate under advisory contracts or declarations of trust that impose restrictions in situations in which the possibility for self dealing is present. Hence, the declarations of trust under which almost all externally-managed REITs operate stipulate that all transactions between the REIT and its adviser or affiliates of the adviser must be approved by a majority of trustees not affiliated with the adviser or its affiliates. ${ }^{42}$ Almost all declarations further specify that such transactions must be "fair and reasonable" to the shareholders of the trust and must embody terms no less advantageous to the trust than terms obtainable in similar transactions consummated at arms-length. ${ }^{43}$ A number of REITs and advisers have incorporated further provisions into the advisory contract that are designed to ensure that an adviser who is originating loans for its own account will also fairly allocate desirable investment opportunities to the REIT. Under certain advisory contracts, the REIT may require its adviser to participate as a co-lender on equal terms ("pari passu") up to a fixed percentage of any loan recommended by the adviser and extended by the trust, or may participate itself up to a fixed percentage in loans extended by the adviser. ${ }^{44}$ A limited number of REITs have also incorporated into the advisory contract a "right of first refusal," giving the REIT the first option to acquire allowable investments before the adviser may acquire such investments for its own account. 45

42 See Appendix A.

$43 \mathrm{Id}$.

44 Id. Of the 10 largest externally-managed REITs surveyed, five incorporated pari passu provisions in their advisory contracts. Of the five, four provided for participation by the adviser in loans recommended to the trust; the maximum participation required of the adviser in these cases was 15 percent. One contract allowed for participation by the trust in loans made by the adviser or its affiliates; the maximum allowable participation thereunder was 10 percent. Id.

$45 \mathrm{Id}$. Of the $10 \mathrm{REITs}$ surveyed, only three incorporated such provisions in their advisory contracts. Under one of the three contracts, moreover, although the REIT could request that the adviser make any of its investment opportunities available to the REIT, the adviser was not required to do so, in which case the non-affiliated trustees' only recourse was cancellation of the advisory contract. See Equitable Life Mortgage and Realty Investors, Prospectus dated Oct. 29, 1970 , at 26. 
The foregoing protections, unfortunately, are only of limited value. Although trustees are required to find, after full disclosure, that transactions between the REIT and affiliated entities are "fair and reasonable," the sanctions for failure to exercise due care in making this determination are questionable at best. Almost all REIT declarations of trust contain a broad exculpatory clause relieving the trustees as well as the adviser from liability for all but intentional or "gross and reckless" acts; ${ }^{46}$ under common law principles in many jurisdictions the validity of such provisions has been upheld. ${ }^{47}$ For reasons to be articulated, moreover, the common law "duty of care," which arguably applies to REIT trustees charged with detecting and preventing self-dealing managerial transactions, is an inadequate protection absent the imposition of a meaningful standard of liability upon such trustees. ${ }^{48}$

The "pari passu" and "first refusal" provisions are similarly limited. Not all REIT advisory contracts incorporate such provisions. ${ }^{49}$ Some incorporate one and not the other; some incorporate neither. The pari passu provision, when utilized, often requires the adviser to participate only to a limited extent-in most cases as little as ten percent-in the loans that it recommends to the REIT. ${ }^{50}$ The right of first refusal is, in theory, a significant protection for the REIT in that it ensures that the REIT will have "first crack" at desirable investment opportunities that become available to the adviser. As previously indicated, ${ }^{51}$ however, the use of first refusal provisions is limited. Moreover, it is questionable whether in practice the REIT's nonaffiliated trustees can or should be expected to scrutinize meaningfully every investment opportunity that becomes available to the adviser on the "first refusal" basis, particularly when the adviser originates or receives a large number of investment opportunities in the course of its operations.

\section{Restrictions Imposed by State Law}

In addition to self-imposed protections, statutory as well as common law principles in most states contain restrictions that have

46 See Appendix A. The typical exculpatory clause contains the following restrictions: "No Trustee, officer or agent of the Trust is liable to the Trust or to a shareholder except for his own bad faith, wilful misfeasance, gross negligence, or reckless disregard of his duties." Continental Illinois Realty, Registration Statement on Form S-11 dated Dec. 20, 1972 (Amend. No. 1), at 37.

47 See G. Bogert, HaNDBooK of the Law of Trusts $\$ 94$ (5th ed. 1973).

48 See notes 65-70 infra \& accompanying text.

49 See note 44 supra.

50 See Appendix A.

51 See note 45 supra. 
relevance to conflicts of interest in REIT management. A number of existing state statutory regulations dealing with securities offerings by REITs ${ }^{52}$ are patterned after the Statement of Policy regarding REITs ("Statement of Policy" "Policy") adopted by the Midwest Securities Commissioners Association ("MSCA"). ${ }^{53}$ Under the provisions of the Statement of Policy, REIT offerings may be deemed "unfair and inequitable" unless the REIT's organizational instruments impose certain restrictions designed to minimize conflicts of interest and self-dealing in the management of the REIT. Principally, these provisions require (1) that a majority of trustees not be affiliated with the adviser of the trust or any affiliate thereof; ${ }^{54}$ and (2) that trustees and officers of, and the adviser to any trust may not sell to or purchase from the trust any assets except in specified instances, and only then with the approval of a majority of the independent trustees. ${ }^{55}$

Although the foregoing limitations are unquestionably salutary as far as they go, they have neither been widely accepted nor have

52 For a comprehensive discussion of state "blue sky" statutes and REITs, see Polubinski, The Effect of State Securities or Blue Sky Law Regulation Upon the Organizational Structure and Operations of Real Estate Investment Trusts, 30 Bus. LAWYER 179 (1974).

53 Id. 180-81.

54 Subsection A provides: "Trustees. A majority of the trustees shall not be affiliated with the adviser of the trust or any organization affiliated with the adviser of the trust. The trustees shall be elected by the shareholders of the trust annually." I BLUE SKY L. REP. (CCH) I 4801.

65 Subsection B provides:

Self Dealing. No trustee, officer, or adviser of a trust, or any person affiliated with any such persons, shall sell any property or assets to the trust or purchase any property or assets from the trust, directly or indirectly, nor shall any such person receive any commission or other remuneration, directly or indirectly, in connection with the purchase or sale of trust assets, except pursuant to transactions that are fair and reasonable to the shareholders of the trust and that relate to:

1. the acquisition of property or assets at the formation of the trust or shortly thereafter that is fully disclosed in the prospectus;

2. the acquisition by the trust of federally insured or guaranteed mortgages at prices not exceeding the currently quoted prices at which the Federal National Mortgage Association is purchasing comparable mortgages;

3. the acquisition of other mortgages on terms not less favorable to the trust than similar transactions involving unaffliated parties; or

4. the acquisition by the trust of other property at prices not exceeding the fair value thereof as determined by independent appraisal.

All such transactions and all other transactions in which any such persons have any direct or indirect interest shall be approved by a majority of the trustees, including a majority of the independent trustees. All commissions or remuneration received by any such person in connection with any such transactions shall be deducted from the advisory fee.

1 BLUE Sxy L. REP. (CCH) \4801. 
they been sufficient to address all potential conflicts between REITs and their advisers. Hence, as of this writing, only seven states ${ }^{56}$ and the American Stock Exchange have enacted rules or regulations modeled upon the MSCA Statement of Policy. ${ }^{57}$ Seven other states ${ }^{58}$ have adopted rules that deal specifically with REITs but that are substantially more limited in scope than the MSCA Statement of Policy. Of the states that have formally adopted rules dealing with REITs, almost all exempt REIT offerings if the shares are listed on the New York Stock Exchange. ${ }^{59}$ Significantly, as of August 1977, the shares of at least thirty-seven REITs, representing over forty-one percent of total industry assets, qualified for this exemption.60 Finally, the MSCA guidelines apply only to new offerings of securities; they have no applicability when REITs finance through commercial paper and bank lines of credit.

Apart from the limited application of the MSCA Statement of Policy, the Policy itself ignores certain important conflict problems. The provisions that address self-dealing are limited to situations involving purchases and sales of assets between the trust and its in-

56 Alaska, 1 Blue Sky L. Rep. (CCH) đ 6046; Iowa, IA Bute SkY L. Rep. (CCH) T18,642; Kansas, 1A BuUE SKY L. REP. f 19,707; Missouri, 2 BLuE SkX L. ReP. (CCH) đ 28,65I; Tennessee, 3 BLUE SKX L. REP. (CCH) đ 45,626; Wisconsin, 3 Blue SKy L. Rep. (CCH) \52,732; Wyoming, 3 BluE SKy L. Rep. ( $\mathrm{CCH}) \llbracket 53,614$.

57 Other states have informally acknowledged adherence, in varying degrees, to the MSCA Policy, but have not adopted rules or regulations incorporating the Policy in whole or in part. See Polubinski, supra note 52, at 198-201 (Table II).

58 States that have adopted 'rules or regulations relating to the organization and business activities of REITs include: California, 1 BLUE SKY L. REP. (CCH) I 8598; Florida, I BluE Skx L. REp. (CCH) \13,623; Idaho, 1A BLuE Skx L. REP. (CCH) If 15,701-15,713; Michigan, IA BLUE SKx L. REP. (CCH) IT 25,63825,652; Mississippi, 1A Blue Sky L. Rep. (CCH) গ27,641; Washington, 3 BLuE SKY L. REP. (CCH) $\uparrow 50,607$. Of the foregoing states, California, Idaho and Washington have no regulations limiting self-dealing transactions between the REIT and its trustees, investment adviser, or their respective affiliates.

Three states have adopted rules or regulations that only require certain disclosures in connection with REIT offerings but do not otherwise regulate organization or business activities thereof: New Jersey, 2 BLUE SKY L. Rep. (CCH) I 33,761; New York, 2 BluE SKY L. Rep. (CCH) T35,611; Virginia, 3 BLuE Sky L. REP. (CCH) $\llbracket \llbracket 49,613,49,615$.

59 Of states adopting regulations applying to REIT offerings, 11 exempt shares from their respective securities statutes if such shares are listed on the New York Stock Exchange. AJ.ASRA STAt. \$45.55.140(a)(10) (Supp. 1977); CaI. Corp. Code $\$ 25100$ (o) (West Supp. 1978); Fla. Stat. ANN. \$517.05(6) (West 1972) (repealed effective July 1, 1980 (West Supp. 1978)); IDarro CoDE $\$ 30-1434$ (8) (Supp. 1978); Iowa Code ANN. \$502.4(5) (West 1949); Kan. STAT. \$17-1261(g) (Supp. 1977); Mrch. Stat. ANN. \$19.776(402)(7) (1975 rev.); Mo. ANN. Stat. $\$ 409.402$ (a) (8) (Vernon Supp. 1978); N.J. Stat. AnN. $\$ 49-3-50$ (a)(8) (West 1970); Tenn. Code ANN. \$48-1619(F) (1964); Wash. Rev. Code AnN. \$21.20. $310(8)$ (1978); Wyo. Stat. \$17-4-114(a)(vii) (1977). Mississippi, New York and Wisconsin have no exempting legislation for shares listed on national securities exchanges.

60 REIT FACTBOOK, 1977, supra note 1, at 23. 
vestment adviser, trustees and officers, or any of their respective affiliates. Nowhere do the provisions address conflicts of interest inherent in the sale of services to the REIT by the investment adviser or its affiliates, or conflicts that exist when an investment adviser or any of its affiliates are engaged in business activities, including lending and acquisition of real property, in which the REIT is also engaged.61 More significantly, the self-dealing provision relies upon the diligence and good faith of the trust's independent trustees to ascertain the fairness of transactions involving purchases and sales of trust assets. In the absence of the imposition of stringent fiduciary duties on the adviser and the independent trustees, this reliance may be misplaced. ${ }^{62}$

Prevailing common law standards also impose upon corporate officers and directors certain duties that address the supervision of managerial conflicts of interest. Hence, state law imposes upon all corporate directors and, presumably upon trustees of business trusts, ${ }^{63}$ a general duty of care with respect to the conduct of cortion:

61 Only Missouri has adopted a regulation that addresses this conflict situa-

(G) Reasonable safeguards to avoid conflicts of interest shall be established in the case of any adviser or person sponsoring a trust, or parent or any affiliate of the adviser or person sponsoring the trust, who is engaged or may engage in the type or kind of activities within the purposes of the trust, or who is engaged or may engage in furnishing advisory services to persons other than the trust, which advisory services are of the type or kind of services furnished or to be furnished the trust.

2 BLUE SKY L. REP. (CCH) $\llbracket 28,651$.

62 See text accompanying note 145 infra.

63 At least one commentator has questioned whether REIT trustees would be held to the ordinary standard of care imposed upon directors of corporations, or to the more stringent standards imposed upon trustees of an ordinary trust. B. LOREZ, THE Role OF THE "INDEPENDENT" TRustee DN A REIT 3-5 (1974).

Although no case appears to have dealt with the specific issue in the REIT context, a number of courts have noted that there are significant differences between the objectives and operations of an ordinary trust and those of a business trust. Hence, it has been observed that an ordinary trust exists principally to hold and conserve particular assets, whereas a business trust's primary purpose, like that of a corporation, is to conduct a business for profit. E.g., Morrissey v. Commissioner, 296 U.S. 344, 358-60 (1935); Bomeisler v. M. Jacobsen \& Sons Trust, 118 F.2d 261, 265 (1st Cir), cert. denied, 314 U.S. 630 (1941); Brooklyn Trust Co. v. Commissioner, 80 F.2d 865, 867 (2d Cir. 1936). Indeed, in several cases the business trust has been held to be a corporation for certain purposes, Morrissey v. Commissioner, 344 U.S. at 358-60; Loring v. United States, 80 F. Supp. 781, 785 (D. Mass. 1948), and trustees have been held to be the equivalent of corporate directors, Ashworth v. Hagan Estates, 165 Va. 151, 155, 181 S.E. 381, 382 (1935).

Under the rationale of the foregoing cases, it seems doubtful that the standards of care imposed upon the trustees of ordinary trusts would be imposed upon trustees of a business trust. Rather, it seems more probable, given the similarity in function between corporate directors and trustees of a business trust, that trustees of a business trust would be held to the same standard of care as corporate directors. Cf. Saminsky v. Abbott, 40 Del. Ch. 528, 537, 185 A.2d 765, 771 (1961) 
porate affairs and the supervision of the conduct of corporate management. $^{64}$ The duty of care, unfortunately, is of questionable prophylactic value. Significantly, it has been used to impose liability on directors principally when the directors have been personally involved in self-dealing by management ${ }^{65}$ and when there has been a demonstration of a resultant monetary loss to the corporation and its shareholders. ${ }^{68}$ Almost all cases that have held directors liable for mere negligent failure to detect managerial self-dealing have involved banks and similar financial institutions; the cases suggest that a lesser duty is required of directors of non-banking enterprises. ${ }^{67}$ Furthermore, in some jurisdictions, directors may be held liable only for gross negligence, suggesting that a director or trustee cannot be found liable in the absence of actual knowledge of fraudulent self-dealing by managerial personnel. ${ }^{08}$ In this connection, it is significant that Massachusetts law, which governs the liability of many major REITs, ${ }^{69}$ adopts the gross negligence standard. ${ }^{70}$

(common law business trust partakes of most of the attributes of ordinary business corporation); State Street Trust Co. v. Hall, 311 Mass. 299, 302-03, 41 N.E. $2 \mathrm{~d} \mathrm{30,33} \mathrm{(1942)} \mathrm{(business} \mathrm{trusts} \mathrm{closely} \mathrm{resemble} \mathrm{corporations} \mathrm{and} \mathrm{frequently}$ have been considered as such); Smith v. Brown-Borhek Co., 414 Pa. 325, 332-33, 200 A.2d 398, 401 (1964) (discussing impracticality of applying standard of care in ordinary trust situation to business and banking enterprises).

64 See generally 3A W. Fletcher, Cyclopedia of the Law of Prutate Conporatrons \$1070, at 86-95 (rev. perm. ed. 1975).

65 According to one commentator who has surveyed the cases in the area:

The search for cases in which directors of industrial corporations have been held liable in derivative suits for negligence uncomplicated by self-dealing is a search for a very small number of needles in a very large haystack. Few are the cases in which the stockholders do not allege conflict of interest, still fewer those among them which achieve even such partial success as denial of the defendants' motion to dismiss the complaint.

Bishop, Sitting Ducks and Decoy Ducks: New Trends in the Indemnification of Corporate Directors and Officers, 77 YALE L.J. 1078, 1099 (1968) (footnote omitted). Accord, W. Fuetcher, supra note $64, \$ 1070$, at 87 . See also Dyson, The Director's Liability for Negligence, 40 IND. L.J. 341 (1965).

${ }^{66}$ E.g., Barnes v. Andrews, 298 F. 614, 616 (S.D.N.Y. 1924) (Hand, J.) ("The plaintiff must accept the burden of showing that the performance of the [defendant director's] duties would have avoided loss, and what loss it would have avoided.").

67 See, e.g., Atherton v. Anderson, 99 F.2d 883 (6th Cir. 1938); Litwin v. Allen, 25 N.Y.S.2d 667, 678 (Sup. Ct. 1940). See generally W. CARx, CASES AND Materials on Corporations, 525-27 (4th ed. 1969); W. Fletcher, supra note $64, \$ 1068$, at $84-85$; Bishop, supra note 65 , at $1095-99$.

68 W. FLETcher, supra note $64, \S 1034$, at $24-26$.

69 Of the ten largest externally-managed REITs in the country in 1977, seven were Massachusetts business trusts. See Appendix A.

70 Spiegel v. Beacon Participations, Inc., 297 Mass. 398, 411, 8 N.E.2d 894, 904-05 (1937) ("clear and gross negligence"). See also Allied Freightways, Inc. v. Cholfin, 325 Mass. 630, 633, 91 N.E.2d 765, 767 (1950) (director of business 
State law imposes on officers and directors of corporations a correlative duty that is relevant to conflicts of interest in REITs: the duty of loyalty. Although abstractions concerning the duty of loyalty are of little value, it may be said generally that directors and officers must exercise good faith in all transactions involving the corporation and its property, and must demonstrate good faith and inherent fairness in connection with all personal dealings with the corporation. ${ }^{71}$

Although the duty of loyalty imposed by common law appears to provide a useful prophylactic in situations in which conflicts of interest involve REIT officers, directors, and investment advisers, such, unfortunately is not the case. As an initial matter, the duty of loyalty applies principally to officers and directors directly employed by corporations; it is not clear whether it applies in all instances to external investment advisers who manage a business entity pursuant to an advisory contract. ${ }^{72}$ Second, although the duty of loyalty requires a showing of fairness to the corporation on the part of the officer or director who has dealt with it, ${ }^{73}$ a number

corporation not liable for wrongful misconduct of others unless he joined with them in perpetrating the wrong). The gross negligence standard has been severely criticized. See N. LatTIN, THE LAW OF Corporations $\$ 78$, at 274 (2d ed. 1971).

71 See, e.g., Pepper v. Litton, 308 U.S. 295, 306 (1939). See generally W. FLETCHER, supra note $64, \$ 850$, at $175-81$.

$72 \mathrm{Cf}$. Conference on Mutual Funds, 115 U. PA. L. Rev. 663, 745 (1967) (mutual fund advisers are not fiduciaries as to advisory fees) (comment of A. Jaretzki, Jr.). But see Rosenfeld v. Black, 445 F.2d 1337 (2d Cir. 1971). In Rosenfeld, the Second Circuit seemed to hold that an investment adviser to a mutual fund stands in a fiduciary relationship to the fund and its shareholders under common law principles, independently of the federal fiduciary standards established under $\$ 36$ (a) of the Investment Company Act. Id. 1342-44. This principle has been extended to the advisory relationship between a REIT and its adviser in at least one instance involving an Internal Revenue Service ruling. Rev. Rul. 74-471, 1974-2 I.R.B. 198 (corporation as agent is adviser subject to control by trust and also is a trust fiduciary bound by fiduciary duty of loyalty).

73 See, e.g., Pappas v. Moss, 393 F.2d 865, 867 (3d Cir. 1968) (applying New Jersey law); Kennerson v. Burbank Amusement Co., $120 \mathrm{Cal}$. App. 2d 157, 169, 260 P.2d 823, 832 (1953) (citing California statute); Winchell v. Plywood Corp., 324 Mass. 171, 176-77, 85 N.E.2d 313, 317 (1949). Professors Frey, Choper, Leech, and Morris accurately summarize the status of the "fairness" doctrine:

By mid-twentieth century, the rule became further liberalized. Despite the absence of any specific recent ruling on the issue in a number of states, and despite occasional decisions that transactions were avoidable by the corporation regardless of faimess if a majority of the directors had an adverse interest or if an interested director was necessary for a quorum, "it could be said with some assurance that the general rule was that no transaction of a corporation with any or all of its directors was automatically voidable at the suit of a shareholder, whether there was a disinterested majority of the board or not; but that the courts would review such a contract and subject it to rigid and careful scrutiny, and 
of jurisdictions hold that a transaction will be presumed to be fair if it is ratified by the shareholders or approved by a majority of disinterested directors. ${ }^{74}$ Indeed, with respect to contracts between investment trusts and external management companies, when there has been an express or implied ratification by shareholders the common law will not disturb such contracts absent a showing of corporate "waste"-a standard that is a far cry from the "fairness" showing that is normally required under the duty of loyalty doctrine. ${ }^{75}$ As will be demonstrated below, the critical inadequacy of the common law "fairness/waste" doctrine is its failure to provide for an informed and effective decisionmaking process. ${ }^{76}$

The duty of loyalty does not preclude corporate officers and directors from entering into "good faith" competition with the corporation; ${ }^{77}$ thus, for example, no externally-imposed legal standard prohibits a REIT trustee from serving as president of a bank that is active in the real estate loan market. "Good faith" competition is measured by the facts and circumstances of each case, ${ }^{78}$ and even failure to disclose the competing interest is not per se bad faith. ${ }^{79}$ Although it would be unwise to prohibit completely competitive activity by REIT advisers and trustees, a mandatory disclosure requirement would allow the trustees to determine whether such activity is in the best interest of the REIT.

\section{Restrictions Imposed by Federal Law}

The final source of existing regulation that is relevant to the REIT conflict of interest problem is the general disclosure require-

would invalidate the contract if it was found to be unfair to the corporation."

A. Frey, J. Choper, N. Leeech \& C. Morris, Cases and Matertals on CorPORATIONS 169 ( $2 \mathrm{~d}$ ed. 1977) (footnotes omitted).

74 See, e.g., Lipkin v. Jacoby, 42 Del. Ch. 1, 202 A.2d 572 (1964); Saxe v. Brady, 40 Del. Ch. 474, 184 A.2d 602 (1962); Seitz v. Union Brass \& Metal Mfg. Co., 152 Minn. 460, 189 N.W. 586 (1922); Gallen v. National City Bank of New York, 152 Misc. 679,273 N.Y.S. 87 (1934).

75 See notes $174-77$ infra \& accompanying text. It was the apparent laxity of the common law duty of loyalty and the application of the "corporate waste" standard in assessing the fairness of mutual fund advisory contracts that prompted Congress in 1970 to revise $\$ 36$ of the Investment Company Act. See note 203 infra.

i6 See notes 116-36 supra \& accompanying text.

77 W. FLETCHER, supra note 64 , at 187-93.

78 Id. 188.

79 See, e.g., Bancroft-Whitney Co. v. Glen, 64 Cal. $2 d$ 327, 347, 49 Cal. Rptr. 825, 840, 411 P.2d 921, 935-36 (1966); Patient Care Services v. Segal, 32 Ill. App. 3d 1021, 1031-32, 337 N.E.2d 471, 480 (1975). See also Miller v. Miller, 301 Minn. 207, 222 N.W.2d 7I (1974) (nondisclosure a factor in determining whether a fiduciary has improperly usurped a corporate opportunity). 
ments under the Securities Act of $1933^{80}$ ("1933 Act") and the Securities Exchange Act of $1934{ }^{81}$ ("1934 Act"), which apply with equal force to corporate directors and REIT trustees. ${ }^{82}$ The relevant provisions include section 11 of the 1933 Act ${ }^{83}$ (liabilities for misstatements and omissions in documents offering securities for sale), section 17 of the 1933 Act ${ }^{84}$ (liabilities for misstatements and omissions in connection with offers or sales of securities), section 10 (b) of the 1934 Act ${ }^{85}$ and rule $10 \mathrm{~b}-5$ thereunder ${ }^{86}$ (liabilities for misstatements and omissions in connection with purchases and sales of securities), and section 14(a) of the 1934 Act ${ }^{87}$ and rule 14a-9 thereunder ${ }^{88}$ (liabilities for misstatements in connection with solicitation of proxies). In connection with the disclosure requirements under each of these provisions, it is arguable that the trustees of a REIT-particularly the independent trustees-have a statutory duty to investigate and require disclosure of all instances of material conflicts of interest and self-dealing involving the REIT-adviser relationship.

Regrettably, the duty of investigation that attends the foregoing disclosure requirements is ambiguous at best and, at worst, nonexistent. Under section 11, it appears that independent directors do have an affirmative duty to exercise due diligence in determining the fullness and accuracy of disclosure. ${ }^{89}$ However, the duty only arises in connection with an issuer's offering documents; it does not require subsequent disclosures by the corporation to its public security holders.

Under section 10 and rule $10 \mathrm{~b}-5$ of the 1934 Act, which apply to all corporate disclosures whether made in connection with an

8015 U.S.C. $\$ \$ 77 \mathrm{a}-77 \mathrm{bbbb}(1976)$.

$81 \mathrm{Id}$. \$ $\$ 78 \mathrm{a}-78 \mathrm{kk}$ (1976).

82 B. Lopez, supra note 63 , at 5.

8315 U.S.C. $\$ 77 \mathrm{k}$ (1976).

$84 \mathrm{Id}$. $\$ 77 \mathrm{q}$.

$85 \mathrm{Id}$. $\$ 78 \mathrm{j}(\mathrm{b})$.

8617 C.F.R. $\$ 240.10 \mathrm{~b}-5$ (1977).

8715 U.S.C. $\$ 78 \mathrm{n}(\mathrm{a})$ (1976). Rule $14 \mathrm{a}-3$ prohibits solicitations that are subject to the Act, unless proxy statements containing the information required by Schedule 14A have been distributed to each person that is being solicited. 17 C.F.R. $\$ 240.14 a-3$ (1977). Item 7 of Schedule $14 \mathrm{~A}$ requires disclosure of the interests of certain persons, including directors and officers, who engage in transactions with the issuer or its subsidiary. 17 C.F.R. $\$ 240.14 a-101$ (1977).

8817 C.F.R. $\$ 240.14 a-9$ (1977).

89 See generally Escott v. BarChris Construction Corp., 283 F. Supp. 643 (S.D.N.Y. 1968). See also Ernst \& Emst v. Hochfelder, 425 U.S. 185, 200, 208 (1976) (dicta). In fact, $\S 11(\mathrm{~b})$ of the 1933 Act specifically imposes upon directors a duty of "reasonable investigation." 15 U.S.C. $\$ 77 \mathrm{k}(\mathrm{b})(3)(1976)$. 
initial offering or subsequent thereto, ${ }^{90}$ the courts have not been receptive to the argument that failure of independent directors to investigate is a sufficient predicate for liability. In the leading case, Lanza v. Drexel \& Co., ${ }^{91}$ the Second Circuit reasoned that liability under section 10 and rule $10 \mathrm{~b}-5$ in a private civil action may be sustained only if the director-defendant may be shown to have acted knowingly or in willful or reckless disregard of facts indicating misstatements in information disseminated to investors. ${ }^{92}$ The Lanza standard is consistent with the Supreme Court's decision in Ernst \& Ernst $v$. Hochfelder, ${ }^{93}$ which interpreted the scienter requirement of section 10(b) in the context of shareholder actions. Ostensibly, the Lanza standard would preclude the imposition of liability upon a REIT's independent trustees for failure to discover and require disclosure of self-dealing by management absent a showing that such trustee actually knew of the existence of such self-dealing. ${ }^{94}$

90 For purposes of $\S 10$ and rule 10b-5, it is immaterial that a corporation is not engaged in the offer, purchase, or sale of its securities at the time it issues a false or misleading statement or report. Heit v. Weitzen, 402 F.2d 909 (2d Cir. 1968), cert. denied, 395 U.S. 903 (1969); SEC v. Texas Gulf Sulphur Co., 401 F.2d 833, 839 (2d Cir. 1968) (en banc), cert. denied sub nom. Coates v. SEC, 394 U.S. 976 (1969).

91479 F.2d 1277 (2d Cir. 1973).

92 The Lanza court contrasted the $\$ 10$ requirements with the "absolute liability (except for the due diligence defense)" imposed by $\$ 11$ of the 1933 Act. Id. 1283. The court also noted that even in those $\$ 10$ cases in which courts had endorsed a negligence standard, the conduct at issue had amounted to a violation of a higher standard. Id. 1304.

93425 U.S. 185 (1976). In Hochfelder, the Court held that scienter must be pleaded and proved in private actions under $\S 10$ and rule $10 \mathrm{~b}-5$ of the 1934 Act. The Court stated in a footnote that it "need not address the question whether scienter is a necessary element in an [SEC] action for injunctive relief under section $10(\mathrm{~b})$ and rule 10b-5." Id. $194 \mathrm{n} .12$. The Court also left undecided the issue whether reckless disregard is a sufficient predicate for civil liability under the antifraud section, although a number of post-Hochfelder decisions have so held. See, e.g., Sanders v. John Nuveen \& Co., 554 F.2d 790, 795-96 (7th Cir. 1977); Franke v. Midwestern Okla. Dev. Auth., 428 F. Supp. 719 (D. Okla. 1976); McLean v. Alexander, 420 F. Supp. 1057, 1080-81 (D. Del. 1976); SEC v. Bausch \& Lomb, Inc., 420 F. Supp. 1226, 1242-43 n.4 (S.D.N.Y.), aff'd, 565 F.2d 8 (2d Cir. 1977).

94 At least two recently decided cases have applied the Lanza standard to the conduct of independent trustees of a REIT. Steinberg v. Carey, 439 F. Supp. 1233 (S.D.N.Y. 1977); Gross v. Diversified Mortgage Investors, 431 F. Supp. 1080, 1088 (S.D.N.Y. 1977). In Steinberg, the plaintiffs sued the nonaffiliated trustees of C.I. Realty Investors, a hybrid REIT, for misstatements and omissions in a prospectus issued by C.I. Realty in connection with a 1972 securities offering. In granting summary judgment for three of the nonaffliated trustees, the court found that plaintiffs had not demonstrated sufficient knowledge of the misstatements and omissions to meet the standards in Lanza or Hochfelder. The result in Steinberg is strange in that plaintiffs chose to base their action on $\$ 10$ (b) and rule $10 \mathrm{~b}-5$ of the 1934 Act rather than on $\$ 11$ of the 1933 Act. Under the latter section, of course, plaintiffs 
The case law interpreting the duty of inquiry imposed on independent directors under section 17(a) of the 1933 Act is in a state of flux. Although section 17 and rule $10 \mathrm{~b}-5$ are worded almost identically, the former section applies by its terms only to persons who offer or sell securities; section $10(\mathrm{~b})$ and rule $10 \mathrm{~b}-5$ apply to sellers as well as purchasers. The post-Hochfelder courts that have considered the question of the requisite standard of proof have split on whether scienter is a necessary element of SEC enforcement actions under section 17(a). In one case brought by the SEC that involved allegations of nondisclosure on the part of REIT management, the court ruled that section 17(a), like section $10(\mathrm{~b})$, required a showing of actual intent to defraud. ${ }^{95}$ Other courts have held that mere negligence is a sufficient predicate for liability under section 17(a) in injunctive actions brought by the SEG. ${ }^{98}$

The final provisions of the federal securities laws that are relevant to disclosures of conflicts of interest are sections 14(a) of the 1934 Act ${ }^{97}$ and rule $14 \mathrm{a}-9$ thereunder. ${ }^{98}$ Broadly speaking, these provisions proscribe, in terms similar to those used in section 10 (b) and rule $10 \mathrm{~b}-5$, material misstatements in connection with solicitation of shareholder proxies. Unlike section $10(\mathrm{~b})$ and rule 10b-5, however, at least one circuit after Hochfelder has held that scienter is not a necessary element of a cause of action under section 14(a) and rule 14a-9, and that mere negligent failure to comply with these provisions will suffice.98 Unfortunately, the decision did not go further to impose a broad duty of investigation upon independent directors relative to conflicts of interest or self-dealing; indeed, the court expressly based the liability of the defendant di-

would not have been required to plead or prove scienter, and could have prevailed by proving negligence.

In Gross, plaintiff shareholders, in a consolidated action, sued Diversified Mortgage Investors and various officers and trustees thereof, among others, principally alleging violations of $\S 10$ of the Exchange Act and rule $10 \mathrm{~b}-5$. The court acknowledged the applicability of the Lanza scienter requirement, and held that plaintiffs had sufficiently pleaded scienter, although it dismissed most of the complaint's substantive counts on other grounds.

95 SEC v. American Realty Trust, Inc., 429 F. Supp. 1148, 1171 (E.D. Va. 1977) (appeal pending). See also SEC v. Cenco, Inc., 436 F. Supp. 193, 199-200 (N.D. IIl. 1977).

96 SEC v. Coven, 581 F. 2d 1020 (2d Cir. 1978); SEC v. World Radio Mission, Inc., 544 F.2d 535, 541 n.10 (Ist Cir. 1976); SEC v. Geotek, 426 F. Supp. 715, 726 (N.D. Cal. 1976).

9715 U.S.C. $\$ 78 \mathrm{n}(1976)$.

9817 C.F.R. $\$ 240.14 a-9$ (1977).

99 Gould v. American Hawaiian S.S. Co., 535 F.2d 761 (3d Cir. 1976). 
rectors upon their approval of a proxy statement that misrepresented facts about which they had firsthand knowledge. ${ }^{100}$

Although the disclosure requirements of the 1933 and 1934 Acts operate as a valuable source of information about conflicts of interest, and probably reduce the incentive to engage in such transactions, they offer insufficient protection against the acute problems presented by the REIT industry. The disclosure provisions require very little of the trustees in terms of investigation and nothing with respect to consideration of alternatives to the proposed conflict of interest transaction. In an industry that is characterized by massive conflict of interest problems, after the fact disclosure, even when coupled with the threat of suit by shareholders or the SEC, is no substitute for informed decisionmaking by independent trustees.

\section{The Investment Company Act-Approaches to Conflicts of Interest}

In the Investment Company Act, Congress sought to minimize abuses arising from managerial conflicts of interest (1) by placing outright prohibitions or restrictions on specified classes of transactions between investment companies and certain affiliated entities; and (2) by imposing general fiduciary obligations on specified classes of persons, including the nonaffiliated or "disinterested" directors of regulated investment trusts. Both provisions are instructive in terms of possible legislative approaches to the conflict of interest problems present in the REIT.

The prohibitions on transactions involving investment companies and various classes of individuals whose interests may conflict with those of the company are found principally in section 17 of the Act. ${ }^{101}$ Broadly speaking, section 17 was designed to prevent over-

$100 \mathrm{Id}$. At least two district courts since Gould have also applied a negligence standard in connection with alleged violations of the proxy provisions of the 1934 Act. In re Clinton Oil Securities Litigation, [1977-78] FED. SEC. L. REP. (CCH) (T 96.015 (D. Kan. 1977); Billet v. Storage Technology Corp., 72 F.R.D. 583, 585 (S.D.N.Y. 1976).

10115 U.S.C. $\$ 80 \mathrm{a}-17$ (1976).

The Investment Company Act contains a number of other prohibitions on specific transactions designed in whole or in part to minimize conflicts of interests. These include: $\$ 10(f)$ (prohibitions relating to the purchase or acquisition of securities in offerings involving certain affliated underwriters); $\$ 12(b)$ (prohibitions on an openend fund underwriting its own shares); $\$ 12$ (d) (limitations on ownership by investment companies of shares in other investment or insurance companies, brokerdealers, underwriters, or investment advisers); and $\$ 23$ (prohibitions relating to distributions and repurchase of securities by closed-end companies). Because these sections have little applicability to the operations of REITs, they will not be considered here. 
reaching by all persons who might influence the management of the investment company in connection with transactions that could be used to benefit such individuals personally. ${ }^{102}$ This group of persons includes all "affiliates" of regulated investment companies, a broad class of individuals and companies who may have direct or indirect control relationships with the investment company. ${ }^{103}$

Section 17 and the rules thereunder prohibit four types of affiliated transactions: (1) transactions involving purchases and sales of assets between investment companies and affiliates, promoters, or underwriters thereof; ${ }^{104}$ (2) extensions of credit by investment companies to certain affiliated persons; ${ }^{105}$ (3) transactions in which an investment company and an affiliate or principal underwriter are joint or joint and several participants; ${ }^{106}$ and (4) receipt of com-

102 See, e.g., E.I. duPont de Nemours \& Co. v. Collins, 432 U.S. 46, 53 (1977); United States v. Deutsch, 451 F.2d 98, 108 (2d Cir. 1971), cert. denied, 404 U.S. 1019 (1972); Securities \& Exchange Comm'n, Investment Company Act Release No. 5128 (Oct. 13, 1967).

103 Under $\S 2(a)(3)$ of the Act, an "affiliated person" of another person includes the following:

(A) any person directly or indirectly owning, controlling, or holding with power to vote, 5 per centum or more of the outstanding voting securities of such other person; (B) any person 5 per centum or more of whose outstanding voting securities are directly or indirectly owned, controlled, or held with power to vote, by such other person; (C) any person directly or indirectly controlling, controlled by, or under common control with, such other person; (D) any officer, director, partner, copartner, or employee of such other person; (E) if such other person is an investment company, any investment adviser thereof or any member of an advisory board thereof; and (F) if such other person is an unincorporated investment company not having a board of directors, the depositor thereof.

15 U.S.C. $\$ 80 \mathrm{a}-2(\mathrm{a})(3)$ (1976). In addition to prohibitions on transactions between investment companies and affliates, certain provisions of $\$ 17$ also prohibit transactions between investment companies and principal underwriters ( $\$ \S 17$ (a) \& (d)) and promoters $(\S 17(\mathrm{a}))$.

104 Section $17(\mathrm{a})(1)-(2), 15$ U.S.C. $\$ \$ 80 a-17(a)(1)-(2)$ (1976).

105 Section $17(\mathrm{a})(3), 15$ U.S.C. $\$ 80 \mathrm{a}-17(\mathrm{a})(3)$ (1976). Section $17(\mathrm{a})(3)$ allows borrowing of money or other property pursuant to $\$ 21(\mathrm{~b})$. The latter provision prohibits loans to controlling persons or persons under common control with the investment company, but exempts from the prohibition the extension or renewal of a loan made prior to the effective date of the Act and any loan to a company owning all the outstanding securities of the lender. 15 U.S.C. \$80a-21(b) (1976).

106 Section 17 (d), 15 U.S.C. $\$ 80$ a-17(d) (1976), and rule 17d-1 thereunder, 17 C.F.R. $\$ 270.17 \mathrm{~d}-1$ (1977).

The terms "joint" and "joint and several" are not defined in the Act and have been the subject of only limited judicial construction. See, e.g., SEC v. Talley Industries, Inc., 399 F.2d 396 (2d Cir. 1968), cert. denied sub nom. General Tire Corp. v. SEC, 393 U.S. 1015 (1969). In view of the ostensible purpose of $\$ 17$, however, it is reasonable to conclude that the terms contemplate any transaction by an affiliate or principal underwriter in which the investment company must also take some action with its assets. This would not only include the obvious case involving direct transactions between the investment company and an affiliate, but also situations in which the investment company and its affiliate agree to purchase or sell 
pensation by affiliates acting as agents for the purchase or sale of property to or for an investment company other than in the course of such person's business as an underwriter or broker, and, in the case of brokers, receipt of compensation in connection with purchases and sales of securities in excess of defined amounts. ${ }^{107}$ The SEC may, pursuant to an application, exempt proposed transactions falling within the prohibitions of either sections 17(a) or 17(d) and rule $17 \mathrm{~d}-1$ upon the making of findings designed to ensure the essential fairness of the proposed transaction to the investment company and its shareholders. ${ }^{108}$

The second principal mechanism utilized by the Investment Company Act to regulate conflicts of interest is found in sections 10 (a) ${ }^{109}$ and $36(a){ }^{110}$ of the Act. Under section 10(a), registered investment companies are required to have a board of directors comprised of persons no more than sixty percent of whom are "interested persons" with respect to such company; section $2(a)(19)^{111}$ of the Act defines "interested persons" to include, inter alia, six classes of persons with respect to investment companies, including affiliates of such companies, members of the immediate families of affiliates, legal counsel, and certain "interested persons" of the com-

shares in another company. See id.; SEC v. Midwest Technical Development Corp. [1961-64 Transfer Binder] FEd. SEc. L. Rep. (CCH) 『 91,252, at 94,154 (D. Minn. 1963).

107 Section $17(\mathrm{e}), 15$ U.S.C. $\$ 80 \mathrm{a}-17(\mathrm{e})$ (1976). See generally United States v. Deutsch, 451 F.2d 98 (2d Cir. 1971), cert. denied, 404 U.S. 1019 (1972). 108 The findings required to qualify for an exemption for a transaction covered by $\$ 17(\mathrm{a})$ are stated in $\S 17(\mathrm{~b})$ :

(1) the terms of the proposed transaction, including the consideration to be paid or received, [must be] reasonable and fair and . . . not involve overreaching on the part of any person concerned;

(2) the proposed transaction [must be] consistent with the policy of each registered investment company concerned, as recited in its registration statement and reports filed under this Subchapter; and

(3) the proposed transaction [must be] consistent with the general purposes of this Subchapter.

15 U.S.C. $\$ 80 \mathrm{a}-17$ (b) (1976).

Rule 17d-1(b) provides:

In passing upon such applications [for exemption from $\S 17(d)$ and rule 17d-1], the Commission will consider whether the participation of such registered or controlled company in such joint enterprise, joint arrangement or profit-sharing plan on the basis proposed is consistent with the provisions, policies and purposes of the act and the extent to which such participation is on a basis different from or less advantageous than that of other participants.

17 C.F.R. $\$ 270.17 \mathrm{~d}-1(\mathrm{~b})$ (1977).

10915 U.S.C. $\$ 80 \mathrm{a}-10$ (a) (1976).

110 Id. $\$ 80 \mathrm{a}-36(\mathrm{a})$.

111 Id. $\$ 80 \mathrm{a}-2(\mathrm{a})(19)$. 
pany's investment adviser or principal underwriter. Section 36(a) ${ }^{112}$ broadly proscribes "breaches of fiduciary duty involving personal misconduct" by any officer, director, or investment adviser of any regulated investment company, and vests in the SEC jurisdiction to seek to enjoin such breaches. ${ }^{113}$ A number of courts that have considered the issue have also found an implied private cause of action under section $36(\mathrm{a}) .{ }^{114}$

Although superficially unrelated, sections 10(a) and 36(a) together represent an integrated approach to insulating regulated investment companies from managerial conflicts of interest. In section 10(a), Congress sought to create a class of directors whose interests are completely independent of the interests of management and management's affiliates; it was contemplated that those directors would perform a "watchdog" function with respect to the activities of interested directors and management, especially when those activities represented potential conflicts with the interests of the fund. ${ }^{115}$ The fiduciary provisions of section $36(\mathrm{a})$, in turn, have been interpreted to effectuate the watchdog function of the disinterested directors by imposing stringent disclosure requirements

112 Id. $\$ 80 \mathrm{a}-36$ (a).

113 Section 36(a) provides, in relevant part:

The [Securities and Exchange] Commission is authorized to bring an action ... alleging that a person serving or acting in one or more of the following capacities has engaged within five years of the commencement of the action or is about to engage in any act or practice constituting a breach of fiduciary duty involving personal misconduct in respect of any registered investment company for which such person so serves or acts-

(1) as officer, director, member of any advisory board, investment adviser, or depositor; or

(2) as principal underwriter, if such registered company is an open-end company, unit investment trust, or face-amount certificate company.

If such allegations are established, the court may enjoin such persons from acting in any or all such capacities either permanently or temporarily and award such injunctive or other relief against such person as may be reasonable and appropriate in the circumstances, having due regard to the protection of investors and to the effectuation of the policies declared in section $I(b)$ of this title.

15 U.S.C. $\$ 80 \mathrm{a}-36$ (a) (1976).

114 See, e.g., Moses v. Burgin, 445 F.2d 369, 373 (1st Cir.), cert. denied sub nom. Johnson v. Moses, 404 U.S. 994 (1971); Esplin v. Hirschi, 402 F.2d 94, 103 (I0th Cir.), cert. denied, 394 U.S. 928 (1968); Tanzer v. Huffines, 314 F. Supp. 189, 193 (D. Del. 1970); Brown v. Bullock, 194 F. Supp. 207, 221 (S.D.N.Y.), affd, 294 F.2d 415 (2nd Cir. 1961). But see Brouk v. Managed Funds, Inc., 286 F.2d 901, 912 (8th Cir. 1961); Monheit v. Carter, 376 F. Supp. 334, 342 (S.D.N.Y. 1974). See generally Crane \& Walker, Who can Sue and Be Sued Under Section 36(a) of the Investment Company Act of 1940, 32 Bus. LAwYER 417 (1977) (espousing view that private parties have no implied cause of action under $\$ 36(\mathrm{a})$ ).

115 See Moses v. Burgin, 445 F.2d 369, 376-81 (1st Cir.), cert. denied sub nom. Johnson v. Moses, 404 U.S. 994 (I971). 
upon fund management with respect to all transactions involving possible conflicts of interest and by requiring that disinterested directors affirmatively consider and weigh all relevant factors and alternatives before passing upon such transactions. ${ }^{116}$

The duties imposed by sections 10(a) and 36(a) are significant in comparison with those imposed by common law fiduciary standards. Ostensibly, section 36(a) places upon persons affiliated with a regulated investment company the fiduciary responsibility to act in a manner that is fair to and consistent with the best interests of the fund and its shareholders. To this extent, it is similar to and effectively incorporates previously-discussed common law standards governing self-dealing by corporate management. ${ }^{117}$ Sections $10(a)$ and 36(a) go substantially further than the common law, however, in two significant respects.

First, section 36(a) requires that in all instances in which there is a possible conflict of interest, all relevant facts be disclosed by management to the disinterested directors. In Moses v. Burgin, the seminal case involving interpretation of an investment adviser's duty of disclosure under section 36(a), the court stated:

Whatever may be the duty of disclosure owed to ordinary corporate directors, we think the conclusion unavoidable that Management defendants were under a duty of full disclosure of information to these unaffiliated directors in every area where there was even a possible conflict of interest between their interests and the interests of the fund. ${ }^{118}$

The imposition of a duty of disclosure on investment advisers whose interests conflict with those of the funds that they manage does not in itself improve upon common law standards. In general, the "faimess" doctrine ${ }^{119}$ requires disclosure of conflicts of interest by officers and directors, ${ }^{120}$ and shareholder ratification only

116 Id. 376.

117 See text accompanying notes 70-75 supra. In Tannenbaum v. Zeller, 552 F.2d 402, 416 n.20 (2d Cir. 1977), the court noted that the fiduciary standards under $\$ 36$ are at least as stringent as those of the common law. See also Galfand v. Chestmutt Corp., 545 F.2d 807, 811 (2d Cir. 1976), cert. denied, 435 U.S. 943 (1978) (Congress intended that conduct under $\S 36(\mathrm{~b})$ be governed by traditional rule of undivided loyalty); Rosenfeld v. Black, 445 F.2d 1337, 1344-45 (2d Cir. 1971), cert. dismissed sub nom. Lazard Frères \& Co. v. Rosenfeld, 409 U.S. 802 (1972).

118 Moses v. Burgin, 445 F.2d 369, 376 (1st Cir.), cert. denied sub nom. Johnson v. Moses, 404 U.S. 994 (1971) (emphasis added).

119 See text accompanying notes 70-76 supra.

120 One commentator has summarized the disclosure requirement as follows: "If the interested fiduciary makes full disclosure to the board of directors, and the 
results in application of the "waste" standard ${ }^{121}$ when it is accompanied by full disclosure. ${ }^{122}$ The significance of the section 36(a) duty lies in its attempt to ensure that the disinterested directors will possess sufficient information to exercise the watchdog function imposed upon them by Congress.

The Moses court emphasized the breadth of the duty of disclosure that is imposed by section 36(a). The court's broad construction of the disclosure requirement was unambiguous:

This duty [of disclosure] could not be put more clearly than was stated by the SEC in 1965.

"The Investment Company Act's requirement as to unaffiliated directors, if its purposes are not to be subverted, carries with it the obligation on the part of the affiliated directors, and the investment adviser itself, to insure that unaffiliated directors are furnished with sufficient information so as to enable them to participate effectively in the management of the investment company."

Except where it may be fairly assumed that every unaffiliated director will have such knowledge, effective communication is called for. And, in testing that assumption, it must be borne in mind that they are not full time employees of the fund and it may be ... that neither their activities nor their experience are primarily connected with the special and often technical problems of fund operation. ${ }^{123}$

transaction is authorized by the board, on the basis of the required quorum and vote, the transaction usually would be properly authorized but with the burden of sustaining the transaction possibly on its proponents." H. HENN, HANDBOOK OF THE LAW of Corporations and Other Business EnTerprises 466 (2d ed. 1970) (footnote omitted). See State ex rel. Hayes Oyster Co. v. Keypoint Oyster Co., 64 Wash. 2d 375,391 P.2d 979 (1964) (director's failure to disclose his position as officer and substantial shareholder in another corporation rendered voidable a contract between the two corporations; without disclosure the transaction was "unfair" per se).

121 See text accompanying notes 74 \& 75 supra.

122 Professor Henn states: "Obviously, shareholder ratification, to have any effect, presupposes full disclosure to the shareholders in solicitating their notes or proxies." H. HeNN, supra note 120, at 469-70 (citing Heilbrunn v. Sun Chemical Corp., 37 Del. Ch. 552, 146 A.2d 757 (Ch. 1958), affd, 38 Del. Ch. 321, 150 A.2d 755 (Sup. Ct. 1959); Eliasberg v. Standard Oil Co., 23 N.J. Super. 431, 92 A.2d 862 (1952), aff'd mem., 12 N.J. 467, 97 A.2d 437 (1953); Berendt v. Bethlehem Steel Corp., 108 N.J. Eq. 148, 154 A. 321 (1931)).

123 Moses v. Burgin, 445 F.2d 369, 376-77 (1st Cir.), cert. denied sub nom. Johnson v. Moses, 404 U.S. 994 (1971) (citation omitted) (emphasis added). One commentator has described the Moses standard of disclosure as follows: "The disclosure demanded is that necessary to enable the disinterested directors to exercise independent judgment as to fund policies that are possibly touched by management self interest. . . . Thus the standard . . . is a pragmatic one-whether management has provided sufficient information to assure 'effective participation' of the inde- 
The court in Tannenbaum $v$. Zeller ${ }^{124}$ endorsed the broad view of Moses, stating that management is required to provide not only "full," but also "effective" disclosure to the independent directors. $^{125}$ In summary, Moses and Tannenbaum, require that management provide the quantum of information that will allow effective oversight by the independent directors.

Although the content of the state law duty varies from jurisdiction to jurisdiction, ${ }^{126}$ it appears that no state requires disclosure of the magnitude contemplated by section 36(a). Many states simply require that the officer or director disclose the interest that conflicts with that of the corporation. ${ }^{127}$ Several states go further and require disclosure of the fiduciary's interest and the material facts concerning the transaction at issue. ${ }^{128}$ The fact that the bare "disclosure of interest" standard is the law in numerous states would in itself justify the imposition of a stringent federal standard. However, even the more demanding "disclosure of facts about the transaction" standard does not equal the Moses requirement. As the Tannenbaum court noted, section 36(a) mandates disclosure of more than information about the conflict of interest transaction; at a minimum, the management must inform the independent directors of possible alternatives to its proposed action. ${ }^{129}$ Moreover, there is no indication that the broader version of the state law duty to disclose requires that management communicate technical information in an understandable fashion; such communication is implicitly (or explicitly) $)^{130}$ contemplated in the Moses "effective participation" criterion.

The second significant difference between common law fiduciary principles and those of sections $10(\mathrm{~b})$ and $36(\mathrm{a})$ relates to the

pendent directors." Comment, Mutual Funds and Independent Directors: Can Moses Lead to Better Business Judgment?, 1972 DuKE L.J. 429, 455.

124552 F.2d 402 (2d Cir. 1977).

125 Id. 427.

126 For some representative statutory provisions that regulate conflict of interest transactions see A. Frex, J. ChOpER, N. LeECH \& C. Morrus, supra note 73, at 172-76. Two commentators list 27 states that have enacted such statutes. Bulbulia \& Pinto, Statutory Responses to Interested Directors' Transactions: A Watering Down of Fiduciary Standards?, 53 Notre DAME LAw. 201 (1977). For a brief discussion of the development and status of the applicable common law rules, see A. FrEY, J. ChOPER, N. LEeCH \& C. Morrus, supra note 73, at 168-69.

127 See, e.g., N.Y. Bus. Corp. Law $\$ 713$ (McKinney Supp. 1976).

128 See, e.g., Dex. Code ANN. tit. 8, § 144 (1975).

129 The court stated: "[W]e conclude that the second prong of the applicable test-that the independent directors were fully informed by the adviser and the interested directors of the possibility of recapture and the alternative uses of brokerage-has been met." 552 F.2d 402, 427 (2d Cir. 1977) (emphasis added). 130 See text accompanying notes 122 \& 123 supra. 
duties of the disinterested directors. As previously discussed, ${ }^{131}$ the common law duty of care ostensibly requires little of outside directors in ferreting out self-dealing by inside directors and management personnel. In many jurisdictions, it is necessary to demonstrate complicity on the part of the outside directors, or, at the least, actual knowledge of managerial self-dealing, to sustain liability. ${ }^{132}$ Under sections 10(a) and 36(a), however, the legislative history makes it clear that directors may be liable for breaches of fiduciary duty arising from nonfeasance (i.e., negligent failure to discover self-dealing) as well as misfeasance. ${ }^{133}$ More significantly, judicial interpretations of the Investment Company Act have set forth standards indicating an affirmative duty on the part of disinterested directors to consider diligently all factors relevant to an evaluation of managerial issues involving conflicts between fund and management interests. In Fogel $v$. Chestnutt, ${ }^{134}$ a case involving management's duty to disclose to the disinterested directors the possibility of taking certain actions to recapture brokerage commissions, the court stated:

Congress had mandated independent directors in order "to supply an independent check on management and to provide a means for the representation of shareholder interests in investment company affairs. . . . The minimum requirement to enable the Fund's independent directors to discharge these duties ... was a careful investigation of the possibilities performed with an eye eager to discern them rather than shut against them, and, if these possibilities were found to be real, a weighing of their legal difficulties and economic pros and cons. ${ }^{135}$

131 See notes 65-70 supra \& accompanying text.

$132 I d$.

133 In connection with the 1970 amendments to $\S 36$, the House of Representatives Committee report declared:

[Y] our committee does not intend to limit the Commission under this section to situations where an actual intent to violate the law can be shown or acts of affirmative misconduct. In appropriate cases, nonfeasance of duty or abdication of responsibility would constitute a breach of fiduciary duty involving personal misconduct.

H.R. REP. No. 1382, 91st Cong., 2d Sess. 37 (1970). See also S. ReP. No. 184, 91st Cong., Ist Sess. 36 (1969).

134533 F.2d 731 (2d Cir. 1975), cert. denied, 429 U.S. 824 (1976).

135 Id. 749-50 (citations omitted). See also Tannenbaum v. Zeller, 552 F.2d 402,419 n.24 (1977) (citing Moses and Fogel as creating a dual test that requires both adequate disclosure and exercise of judgment by the unaffiliated directors). In Brown v. Bullock, 294 F.2d 415, 421 (2d Cir. 1961) (en banc), the Second Circuit held that $\S 15(\mathrm{c})$ of the Investment Company Act creates a private cause of action against mutual fund directors who approve an advisory contract without any consideration of the merits of the contract or the services provided thereunder. 
Although the parameters of the Fogel duty are uncertain at this point, its requirements of "careful investigation" and affirmative "weighing" of the available alternatives provide basic safeguards that are lacking in the nebulous "duty of care." ${ }^{136}$

Can legislation seeking to neutralize conflicts of interest and self-dealing between REITs and REIT management profitably adopt the approaches of sections $10(\mathrm{a})$ and $36(\mathrm{a})$ of the Investment Company Act? At a minimum, it is clear that the fiduciary principles embodied in section 36(a) represent a vast improvement over legal duties imposed on REIT trustees and advisers under existing state and federal laws. In essence, section 36(a) places upon management the onus of full and effective disclosure in every area involving possible conflicts of interest between the fund and management. Perhaps more significantly, section 36(a) imposes upon the fund director an affirmative duty to seek out and evaluate all facts germane to transactions containing possible elements of self-dealing, thus exposing him to the risk of personal liability for breach of fiduciary duty. In both respects, the fiduciary principles embodied in section 36(a) demand, with respect to corporate management, a degree of disclosure and informed scrutiny not found under common law principles or the antifraud provisions of the federal securities laws.

The advisability of imposing section 17-type prohibitions, subject to SEC review and approval, on a broad range of affiliated transactions between a REIT and management (or management affiliates) is less clear. It may be expected that application to REITs of a provision similar to section 17 of the Investment Company Act would serve to lessen the possibility of overreaching in several ways. First, the expense and time involved in the application to the Commission for the issuance of an exemptive order would alone discourage many types of transactions, particularly smaller ones, which fall within the class of proscribed activities. Second, affiliates seeking approval for such transactions would presumably take pains to do so on terms that were fair to the REIT and its shareholders in order to obtain the approval of the Commission. Third, the Commission would have an opportunity to scrutinize the transaction and entertain opposing views, after which it could refuse an exemptive order if overreaching or unfairness tainted the transaction.

These procedures, however, are not without disadvantages. The application procedures under sections $17(\mathrm{~b})$ and (d) and rule

${ }^{136}$ For a discussion of the weaknesses of the law concerning the director's duty of care, see notes 62-70 supra \& accompanying text. 
17d-1 can be cumbersome and costly ${ }^{137}$ and could well discourage numerous REIT-adviser/affiliate transactions that otherwise would prove to be mutually advantageous. This undesirable effect would be particularly pronounced if the REIT required a large number of services which, on a transaction-by-transaction basis, involve only modest compensation to the affiliate; such services might include property management, loan servicing, stock transfers, transfers of real property, and commercial banking. In such cases, the adviser (which already has these capabilities) might be willing to provide such services to the REIT on a more economical basis than otherwise possible but for the cost and delay associated with a formal administrative application.

More importantly, it is not clear that the SEG can or should assume the burden of assessing the fairness of transactions involving REITs and their affiliates. The application to REITs of a provision similar to section 17 would require the Commission to pass on a variety of heretofore commonplace affiliated transactions involving REITs, including joint participations in mortgage loans and equity investments, loans by REITs to affiliates, and, in the case of REITs sponsored by lending institutions, swaps of assets by the REIT with the sponsoring institution in return for reductions of outstanding indebtedness. ${ }^{138}$ Given the magnitude of the task as well as the SEG's already substantial review responsibilities under the Investment Company Act, the imposition of statutory fiduciary responsibilities with concomitant public and private civil remedies may serve as a more practicable and effective means of adequately protecting shareholders than the SEG oversight mechanism embodied in section 17 .

\section{Recommendation}

On balance, this author feels that legislation addressed to the problem of conflicts of interest in REITs should rely principally on the plenary review and approval of affiliated transactions by nonaffiliated trustees subject to a statutory fiduciary standard, and should not resort to SEC administrative application procedures. Specifically, the recommended statutory provision should accomplish four objectives.

137 See Rosenblat \& Lybecker, supra note 22 , at 639 . Under current Commission rules, notices of applications for exemptive orders under $\$ \S 17$ (b) and (d) and rule 17d-1 are published in the Federal Register. An application may be set down for hearing at the request of an interested party or on the Commission's own motion. 17 C.F.R. $\$ \$ 270.0-2$ and 270.0-5 (1977).

138 See notes $37-41$ supra \& accompanying text. 
First, it should, like section 10(a) of the Investment Company Act, require a board of trustees comprised of a minimum number of "independent" trustees who have no economic interests that might conflict with those of the trust. ${ }^{139}$ Such a provision should, at a minimum, disqualify as an independent trustee all classes of persons defined as "interested persons" by section 2(a)(19) of the Investment Company Act, including affiliates of the REIT, 140 members of the immediate families of natural persons who are affiliates of the REIT, interested persons of the investment adviser or principal underwriter of the REIT, registered broker-dealers, and all other persons determined by the Commission to a have a "material business or professional relationship" with the REIT.

Second, the recommended provision should define all classes of transactions involving possible conflicts of interest between the REIT and its investment adviser or persons with an economic interest in the adviser. Such a provision should incorporate the classes of "affiliated" transactions set forth in sections 17(a) and (d) and rule $17 \mathrm{~d}-1$ of the Investment Company Act, including all purchases of assets from or sales of assets to a REIT by any affliated person, and all transactions in which a REIT and any affiliated person thereof qualified as "joint" or "joint and several" participants. ${ }^{141}$

Third, the recommended provision should impose on the REIT's investment adviser, including the adviser's officers and directors, a fiduciary duty that requires, at a minimum, disclosure of all factors necessary to determine whether any affiliated transaction, as defined, is in the best interest of the REIT, and is on terms that are fair and reasonable given the terms that would have been obtained in an arms-length transaction. This standard gives content to the "duty of full disclosure" required by the court in Moses $v$. Burgin.142 The provision should also impose on the REIT's trustees a correlative fiduciary duty that requires affirmative consideration by the trustees of all factors relevant to such a determination, and should require a written record that sets out

139 See note 111 supra \& accompanying text.

140 See note 103 supra. Under the Investment Company Act definition, "affiliated persons" of the REIT would principally include: (1) the adviser; (2) officers, directors, employees, and partners of the adviser; (3) any parent of the adviser, including banking institutions, insurance companies, or real estate companies who sponsored the REIT and the adviser; (4) all officers, directors, or employees of the adviser's parent; (5) any subsidiary or other entity under the control of the adviser or its parent; and (6) all officers, directors, and employees of such subsidiaries or controlled entities. See 15 U.S.C. $\$ 80 \mathrm{a}-2$ (a) (3) (1976).

141 See notes $104 \& 106$ supra \& accompanying text.

142 See note 114 supra. 
the factors considered, the weight accorded to each, and the views of the independent trustees. The provision should further require the filing of a quarterly report with the SEG that details the terms of any consummated transaction with an affiliate and includes the trustees' report. ${ }^{143}$ Taken as a whole, the disclosure, affirmative consideration, and filing requirements ensure that the independent trustees will possess the ability and incentive to protect the interests of the investors.

Finally, the proposed legislation should create (a) enforcement jurisdiction in the SEC to seek injunctive relief against management as well as the REIT's trustees for failure to discharge their respective statutory duties, and (b) parallel private civil causes of action for damages and equitable relief. The provision should specify that negligent as well as willful derelictions of the statutory duties would provide a predicate for suit, and should allow monetary recovery by shareholders for breaches of fiduciary duties, irrespective of whether the fiduciary profited as a result thereof. ${ }^{144}$

143 A similar proposal has been advanced by two commentators with respect to proposed revisions of $\$ 17$ of the Investment Company Act. See Rosenblat \& Lybecker, supra note 22, at 634-45. Under that proposal, a three-tier scheme would be established for all transactions now covered by $\$ \$ 17(\mathrm{~b})$ and (d). The first tier would involve de minimis service contracts between an investment company and affiliated persons; such contracts would require no approval by directors or the SEC if provided at the lesser of cost or market price. The second tier would involve larger transactions that the disinterested directors found fair and reasonable, subject to the fiduciary provisions of $\$ 36(a)$. Third tier transactions would encompass all affiliated transactions that the disinterested trustees were unable or unwilling to find to be fair and reasonable. Such transactions would then be the subject of the formal application procedures that now exist under $\$ \$ 17$ (b) and (d).

The author agrees with the foregoing approach in that it places on the independent directors rather than the SEC principal responsibility for determining the fairness of a proposed affliated transaction. Nevertheless, if the directors were unable or unwilling to approve such a transaction, giving the SEC power to make such a determination pursuant to formal application would constitute an unreasonable incursion by government into corporate governance. If directors of a mutual fund (or the independent trustee of a REIT) decide not to approve an affiliated transaction, they have exercised the type of oversight function contemplated by the Investment Company Act and embodied in the proposed legislation advocated herein.

144 One of the principal failings of $\$ 36$ as now worded is its ambiguity with respect to the existence of private causes of action by fund shareholders against the fund's officers, directors, and investment adviser. Under $\$ 36(\mathrm{~b})$ of the Investment Company Act, shareholders of registered investment companies may recover only from persons who receive compensation under advisory contracts as a result of breaches of fiduciary duties in connection with the approval of advisory contracts. It is uncertain whether shareholders may also recover under $\$ 36$ (a) for trustee breaches of fiduciary duty that do not involve receipt of compensation under advisory contracts. See note 114 supra \& accompanying text. If the directors or trustees of a mutual fund or a REIT are to have adequate incentive to discharge their fiduciary functions, however, shareholders of a REIT should be able to recover for breaches of fiduciary trust, whether or not the loss results from approval of an advisory contract and whether or not the fiduciary profited as a result of its illegal conduct. See notes 209-12 infra \& accompanying text. 
A fundamental assumption of this legislative approach is that a REIT's independent trustees are capable of exercising meaningful vigilance over the enumerated transactions. Significantly, studies of the role of independent directors of mutual funds, whose functions are virtually identical to those of the independent trustees of REITs, have concluded that these directors do not perform their duties with either independence or diligence. Among other things, it has been observed that independent directors of mutual funds are generally chosen by the adviser or the affiliated directors, have no staffs of their own, typically have other businesses and occupations, and receive only modest compensation. ${ }^{145}$ However, these studies do not take into account the effect of the 1970 amendments to the Investment Company Act and the Investment Advisers Act that disqualify individuals with family or material business relationships with the adviser from serving as independent directors, ${ }^{146}$ nor do they take account of the more stringent fiduciary standards incorporated in the Act pursuant to these amendments. ${ }^{147}$ More importantly, the studies focus on the overall relationship between the independent director and the adviser; their conclusions about that relationship are not validly generalizable to the independent trustee's role envisioned by this proposal. If such legislation were enacted, the adviser and the independent trustee would be on notice that their conduct with respect to disclosure, investigation, and consideration of the merits and alternatives of the enumerated conflict of interest transactions would be measured by stringent fiduciary standards. The sanction of personal liability for failure

145 Hearings before the Subcomm. on Commerce and Finance of the House Comm. on Interstate and Foreign Commerce, 91st Cong., 1st Sess. 855-58 (1969) (testimony of $\mathrm{H}$. Budge) [hereinafter cited as 1970 Mutual Fund Amendment Hearings]; Securities and Exchange Comm'n, Publit Policy Implications of InvestMENT Company Growth, H.R. Rep. No. 2337, 89th Cong., 2d Sess. 130-31 (1966) [hereinafter cited as Public Policy Implications]; Whanton School of Finance and Commerce, A Study of Mutual Funds, H.R. Rep. No. 2276, 87th Cong., $2 \mathrm{~d}$ Sess. 34 (1962). Indeed, it has been observed that similar constraints hamper the effectiveness of the independent trustees of REITs. See Note, Advisory Succession in Real Estate Investment Trusts, 1974 DUKE L.J. 123, 125-26. Drawing upon practical experience, one REIT expert has observed:

In the few trustees meetings that I have attended, it was quite apparent that the "unaffiliated" trustees had basically been invited to join the club, that they were there as a pleasant part of their overall business relationship with that banking organization. . . [T]o expect them to exercise any kind of independence in that kind of a setting was just truly out of the question.

REIT Hearings, supra note 18, at 121 (statement of K. Campbell). 146 See text accompanying notes 110-12 supra. See also Nutt, $A$ Study of Mutual Fund Independent Directors, 120 U. PA. L. Rev. 179 (1971). 147 See notes 200-06 infra \& accompanying text. 
adequately to perform these duties should provide substantial incentives to independent trustees to exercise carefully their oversight functions in these areas.

\section{Advisory FeEs}

\section{A. Background}

The advisory fee arrangements by which external investment advisers are compensated for the management services performed for the REIT represent a special class of conflicts of interest, because it is in this area that perhaps the greatest incentive for selfdealing by the adviser and adviser-affiliated officers and trustees of the REIT exists. With respect to mutual funds, the Investment Company Act ${ }^{148}$ singles out the advisory fee problem for special treatment, imposing stringent and specific requirements on regulated investment companies, their directors, and their investment advisers, in connection with the negotiation of fees, permissible fee arrangements, and the duration of advisory contracts. With the exception of the general standards set forth in various statements of policy promulgated by the MSCA, ${ }^{149}$ however, REITs and REIT advisers have not been subject to comparable restrictions. As a result of this lack of regulation, as well as factors inherent in the externalized management structure common to most REITs, pronounced incentives for self-dealing by REIT advisers exist in the area of fee compensation.

Again, it is useful at the outset to focus on crucial differences between the internalized management structure of most operating companies and the externalized management of the REIT. In the usual corporate setting, the officers are employed and compensated directly by the company the affairs of which they manage. The fortunes of these officers correspond with those of the company in three significant respects: (1) a decline in earnings and consequent decline in the per share price of voting securities may give rise to significant shareholder dissent and thus facilitate acquisition of voting control by interests hostile to those of existing management; (2) many corporate officers and board members own significant amounts of equity securities in the corporations they manage, and thus have a direct interest in the company's economic performance; and (3) most corporate officers receive, in addition to their fixed

148 Investment Company Act of 1940, ch. 686, 54 Stat. 789 (1940) (currently codified at 15 U.S.C. $\$ \$ 80 a-1$ to $80 a-52$ (1976)).

140 See notes 53-55 supra \& accompanying text. 
salaries, some bonus compensation based upon the performance of the company. These compensation plans, moreover, are required to be disclosed fully if the company qualifies as a "reporting company" under the Securities Exchange Act. ${ }^{150}$

In contrast, the typical REIT adviser is not vulnerable to dismissal by hostile takeover groups. The adviser owns or employs virtually all of the operating and personnel assets of the REIT: the files, the employees, the physical plant. Dismissal of the REIT adviser, even in the event of acquisition of voting control by a hostile takeover group, would be economically unthinkable. ${ }^{151}$ More significantly, the principal economic interest of the adviser is represented by the income it derives from its advisory contract with the REIT, not by ownership of equity securities in the REIT itself..152 Although poor performance on the part of the REIT can result in a decrease in the adviser's income, for reasons to be explained below, this impact may be minimal or nonexistent depending on the fee structure involved. ${ }^{153}$ Finally, the typical REIT adviser does not receive fixed compensation, but instead collects a fee based on asset size and/or portfolio performance. Although the size of the fee is disclosed, the amount of costs and profit is not; therefore, comparisions with fees charged by other REIT advisers are often meaningless. The end result of the external management structure is simple: the REIT adviser has tremendous incentives to increase its own fees, even at the expense of REIT performance.

Prior to the precipitous decline in the fortunes of the REIT industry, the fee arrangements between REITs and their advisers yielded enormous profits to the advisers. One commentator estimates that after-tax profit margins of these advisers were in the thirty to forty percent range, indicating pre-tax margins in the sixty to eighty percent range. ${ }^{154}$ The same commentator has estimated,

150 Proxy Rules, Schedule 14A, Item 7, 17 C.F.R. $\$ 240.14 a-101$ (1977).

151 For a discussion of the difficulties of discharging a mutual fund adviser, see Securtines \& Exchange Comm'n, Report ON PUblic Policy Impurcations of INvestament Company Growtm, H.R. Rep. No. 2337, 89th Cong., 2d Sess. 131 (1966).

152 Financial institutions that sponsor REITs seldom own significant amounts of shares of their REITs. The major exceptions include two relatively small bank sponsored REITs-HNC Mortgage and Realty Investors (sponsored by Hartford National Corporation) and Realty Income Trust (sponsored by Industrial National Corporation). REIT Hearings, supra note 18, at 27 (statement of $\mathrm{K}$. Campbell). See also Schulkin, Real Estate Investment Trusts, Financial Analysts' J., May-June 1971 , at 74.

153 See note 223 infra \& accompanying text.

154 Audit Investment Research, Reatty Trust Compensation Plans For Advisers: Practices And Status, 1974, at 56 [hereinafter cited as REIT CoMpensation Plans, 1974]. 
assuming that expense-to-portfolio ratios in 1975 represented the break-even cost of operating a REIT, that approximately $\$ 170$ million was the minimum cost of operating all REITs; by contrast, the substantially higher expense ratios of the 1972-73 era represented total operating expenses of $\$ 280$ million. ${ }^{155}$ The author concludes, "[t] hese data raise the substantial question of whether fees were not $\$ 100$ or $\$ 110$ million too high during those halcyon days." 156

Prior to 1975, the predominate form of fee arrangement between REITs and their advisers called for compensation of the adviser based on a fixed percentage of the managed assets. According to the 1974 survey of REIT advisory compensation plans by Audit Investment Research, nearly ninety percent of the 112 trusts surveyed compensated their advisers pursuant to such an arrangement. ${ }^{157}$ Of the REITs surveyed, only about twenty-five percent reduced the adviser's percentage as the portfolio size increased, in recognition of economies of scale associated with REIT management. ${ }^{158}$ Moreover, slightly over half of the plans survey included the unfunded portions of closed loans, as well as funded commitments, ${ }^{159}$ in the asset base upon which the adviser's fee was calculated, even though the nonfunded portions of such loans typically do not earn interest.

In addition to the base fee, seventy-five percent of the plans surveyed contained an incentive fee, typically represented by a percentage of trust income over a base return on equity; ${ }^{160}$ none of the

155 Audit Investament Research, REIT Advisony Fee PIans, 1975, at 4 [hereinafter cited as REIT COMPENSATION PLANS, 1975].

$150 \mathrm{Id}$.

157 REIT COMpensation Plans, 1974, supra note 154, at 59. Most plans surveyed-nearly 70 percent-utilized a "first level" compensation base of 1.0-1.2 percent of the defined asset base. Id. The "first level" base might be reduced as portfolio size increased in recognition of the economics of scale associated with REIT management.

$158 I d$.

159 Id. Most REITs do not disburse the total amount of a loan at once, but fund the lender in stages, generally as the project that is being financed is completed. Under a fee arrangement calling for compensation based on funded and unfunded commitments, however, the REIT pays a fee based on the entire loan amount, even though only a portion has been disbursed.

160 Id. 59. Under a typical plan, the adviser receives 10 percent of all income over the amount representing an eight percent return on shareholders' equity. Id. Hence, if a REIT earned $\$ 10$ million in a given fiscal year and had a total shareholders' equity of $\$ 100$ million, the adviser would receive an incentive fee of $\$ 200,000-i . e ., 10$ percent of $\$ 2$ million-the latter figure representing the excess of income over an eight percent return ( $\$ 8$ million) on shareholders' equity. Typically, the return on equity is computed after the deduction of the total advisory fee in determining the REIT's income. 
plans surveyed, however, contained a penalty clause if the return on equity failed to attain an acceptable level.161 About half of the plans survey also yielded incentive compensation based on a percentage of realized net capital gains, ${ }^{162}$ although, once again, none contained penalty clauses if the trust realized net capital losses. ${ }^{183}$ Finally, about two-thirds of the plans surveyed in 1974 provided for additional compensation for REIT advisers based upon performance of services for the REIT that were not covered in the basic management agreement. ${ }^{104}$ Typically, these services included mortgage servicing fees, ${ }^{165}$ forfeited commitment and standby fees, ${ }^{106}$ and mortgage origination fees. ${ }^{167}$

Even a cursory examination of the foregoing fee arrangements reveals a conflict-ridden system in which massive incentives encourage the adviser to increase assets and engage in heavy debt leveraging for the purpose of increasing fee income. The base fee predicated upon total portfolio size created a direct incentive to make investments in real estate and mortgages secured by real estate, irrespective of the quality or risk associated with such investments, even if imprudently heavy borrowing was necessary. ${ }^{168}$ This incentive was further increased by the income received by advisers from borrowers based on loan originations as well as servicing fees based on the amount of "contract paper" in the trust portfolio. Finally, incentive fees based on high returns on equity and/or

161 See id. 59.

162 Id.

$163 \mathrm{Id}$.

164 Id. 24-29, 59.

165 Such services include collections and disbursements on purchase contracts or mortgages acquired by the REIT in connection with real estate sales. See generally id. $29-36$.

166 Standby and takeout commitments represent commitments to provide longterm financing for completed real estate projects based on the satisfaction of a number of conditions precedent. The borrower pays a fixed fee for such a commitment and forfeits all or part of the fee if the conditions are not met. Id.

167 Origination fees are typically paid by the borrower to the REIT adviser as consideration for the adviser's obtaining financing for the borrower from the REIT. Id. observed:

168 See notes $251-54$ infra \& accompanying text. As one commentator has

The honey which drew the commercial banks, along with many others, into sponsorship of REITs was a generous fee structure. Originally the mortgage trusts paid their advisers from $1.0 \%$ to $1.2 \%$ of invested assets to manage the trusts, a fee structure adapted from mutual funds. Typically, these fee schedules included various bonuses, or incentives, for high shareholder return, capital gain, etc. This fee structure obviously provided a strong incentive for REIT advisers to recommend even higher levels of leveraging, for the more invested assets, the higher the fee.

REIT Hearings, supra note 18, at 26 (statement of $\mathrm{K}$. Campbell). 
capital gains, without corresponding penalties for low returns or capital losses, created an incentive to place the trust in high-risk investments as opposed to lower risk ventures with fewer possibilities for extraordinary profits. ${ }^{169}$

Fee arrangements between REITs and their advisers are no longer as profitable as was the case until 1974. With the decline in the fortunes of the REIT industry, many advisers have been forced to reduce compensation to a "cost only" basis. ${ }^{170}$ Some advisers have retained a fee structure calling for compensation based on a percentage of assets but, because of MSGA upper limits on compensation pegged to REIT income or net assets, have been forced to accept vastly reduced fees or no fee at all. ${ }^{171}$ Finally, a large number of REITs simply have severed with their advisers and have become self-administered. ${ }^{172}$

Whether this is a long-term development remains to be seen. With the resurgence of the fortunes of the REIT industry, ${ }^{173}$ it seems at least as likely that a return to the days of conflict-laden fee systems unchecked by statutory restraints or disinterested oversight by nonaffiliated trustees will result. Under these circumstances, regulatory precautions are in order. The next subsection of this Article will focus on existing standards, with a view toward suggesting a more effective regulatory response to the problems posed by REIT advisory compensation arrangements.

\section{B. The Existing Regulatory Approaches}

As against the conflict-laden fee arrangements and the astronomical profits earned by REIT advisers, the legal standards imposed by state and federal law are, at best, inadequate. Under the common law, the advisory contract between an investment company and its adviser and the resulting fee are subject only to the most limited judicial scrutiny. In the leading case, Saxe $v$. Brady, ${ }^{174}$ shareholders of a mutual fund brought suit against the fund's directors and its investment adviser, claiming that the management fee was unreasonable and excessive as a matter of law, and that the nonaffiliated directors had breached their fiduciary duty

169 See note 226 infra.

170 See note 184 infra.

171 See Audit Investmeñt Researce, REIT Compensation Plans 1, 4-15 (1976) [hereinafter cited as REIT Compensation PLANs, 1976].

172 Id. 23-26; National Ass'n of Real Estate Investment Trusts, REITs MoNTErY (April 1978).

173 See note 290 infra \& accompanying text.

17440 Del. Ch. 474,184 A.2d 602 (1962). 
by approving the contract. In dismissing the action, the court passed the issue of the breach of fiduciary duty, and instead emphasized the fact that a majority of the shareholders had ratified the advisory contract. Under those circumstances, the court ruled that, unless the objecting stockholders could demonstrate that the contract amounted to a "waste of corporate assets," 175 the transaction could not be voided, notwithstanding plaintiffs' allegations that the directors, in approving the contract, had acted out of self-interest. ${ }^{176}$

Statements of policy promulgated by the Midwest Securities Commissioners Association, ${ }^{177}$ which have incorporated limitations on the dollar amount of compensation allowable in REIT advisory contracts, constitute a second source of regulation of REIT advisory contracts. The most recent restrictions, in effect since 1970, limit the permissible total costs of REIT operation, principally including the advisory fee, to the larger of twenty-five percent of total REIT income before deduction of the advisory fee, or 1.5 percent of "average net assets." 178 In no event, however, may compensation to the adviser exceed 1.5 percent of total trust assets. ${ }^{179}$

175 The court defined the waste standard in the following terms: "[The court's] examination . . . is limited solely to discovering whether what the corporation has received is so inadequate in value that no person of ordinary, sound business judgment would deem it worth what the corporation has paid." Id. at 486,184 A.2d at 610.

176 Id. at $478,184 \mathrm{~A} .2 \mathrm{~d}$ at 605 .

177 See notes 53-55 supra \& accompanying text.

178 The applicable provision provides, in full:

C. Fees and Expenses. The aggregate annual expense of every character paid or incurred by the trust, excluding interest, taxes, and expenses in connection with the issuance of securities, shareholder relations, and acquisition, operation, maintenance, protection and disposition of trust properties, but including advisory fees and mortgage servicing fees and all other expenses, shall not exceed the greater of:

1. $1 \frac{1}{2 \%} \%$ of the average net assets of the trust, net assets being defined as total invested assets at cost before deducting depreciation reserves, less total liabilities, calculated at least quarterly on a basis consistently applied; or

2. $25 \%$ of the net income of the trust, excluding provision for depreciation and realized capital gains and losses and extraordinary items, and before deducting advisory and servicing fees and expenses, calculated at least quarterly on a basis consistently applied; but in no event shall aggregate annual expenses exceed $172 \%$ of the total invested assets of the trust.

The advisor shall reimburse the trust at least annually for the amount by which aggregate annual expenses paid or incurred by the trust as defined herein exceed the amounts herein provided.

I BLUE SKY LAW REP. (CCH) $\Uparrow 4801$.

$179 I d$. 
Ostensibly, the foregoing limitations should work to mitigate the adviser's incentive to increase portfolio size through excessive leverage and high risk investments for two reasons: (1) under the 1.5 percent of net assets limitation, because total liabilities are deducted from total assets in calculating the limit, a mere increase in portfolio size offset by an equal increase in borrowing costs will, all other things equal, yield the same fee limitations; and (2) the twenty-five percent of income limitation eliminates the incentive to invest in marginal or high-risk assets given the possible negative impact on income that such investments would have if they began to yield rates of return lower than the REIT's cost of borrowing money or, worse, if the borrower was unable to repay the full amount of principal. Hence, assuming that an advisory fee formula yielded a fee equal to or greater than the applicable limit, it would prove profitable to the adviser to increase borrowings only if the proceeds could be invested in assets that yielded more than the trust's cost of borrowing and the adviser's cost of administering the assets. In summary, the MSCA limitation on advisers' fees achieves, to a significant extent, a closer congruence between adviser and investor interests.

For a variety of reasons, however, the MSCA limitations do not represent an adequate regulatory response to the over-leveraging and excessive risk-taking endemic to the REIT industry. First, as previously pointed out, ${ }^{180}$ only a limited number of states and one stock exchange have adopted the MSCA standards. In 1974, five of the ten largest REITs, representing total assets of almost $\$ 2.5$ billion, did not observe MSCA limitations. ${ }^{181}$ Second, the limitations only discourage further leveraging and investments in marginal or high risk investments if the prevailing advisory fee exceeds both the 1.5 percent of net assets and the twenty-five percent of net income limitations. Under certain circumstances, it is quite possible that an adviser to a trust that was earning no income on its investments and that was only modestly leveraged would nevertheless have an incentive to increase the trust's borrowings and invest the proceeds, notwithstanding the quality of the additional investments or the prudence of increased debt lever-

180 See note 58 supra \& accompanying text.

181 These included Continental Mortgage Investors, First Mortgage Investors, Great American Mortgage Investors, Continental Illinois Realty, and Guardian Mortgage Investors. REIT CoMPENSATION PLANs, 1974, supra note 154, at 44, 60-70; REIT Hearings, supra note 18, at 276. 
age. ${ }^{182}$ Third, the MSCA limits ostensibly do not apply to non-fee income received by advisers from borrowers in connection with loan origination, nor to income received by an adviser or its affiliates for services involving "acquisition, operation, maintenance, protection, or disposition of trust properties." 183 Fourth, when the real estate market turned precipitously downward, resulting in operating losses for REIT advisers under the MSGA limitations, a number of REITs simply agreed to abandon the loss-producing limitations and to reimburse their advisers for their costs of operation. ${ }^{184}$ These arrangements conveniently insulated the advisers from operating losses during hard times even though many had made huge profits when times were still good-a classic "heads-I-win, tails-you-lose" situation. Finally, and most significantly, the MSCA limitations are only maximums-general approximations of the outside limits on permissible fees. They are not in any sense an appropriate substitute for reasoned evaluation of the variety of factors that should be considered in determining the appropriateness of specific advisory compensation arrangements.

The federal securities laws do not directly address REIT's advisory fee arrangements. ${ }^{185}$ Recently, however, the staff of the SEC has taken the position that failures to disclose departures from typical investment management fee schedules are violative of the

182 Suppose, for instance, that a trust had $\$ 500$ million in invested assets, $\$ 100$ million in liabilities, and $\$ 400$ million of shareholders equity:

$\begin{array}{lllll}\text { Assets } & \$ 500 & : & \text { Long-term debt } & \$ 100 \\ & & : & \text { Shareholder equity } & \$ 400\end{array}$

Suppose also that the trust had no income in a given year and that the advisory contract called for an annual fee of one percent of total assets.

The fee to the adviser would be $\$ 5$ million; the upper limit on the fee would, however, be $\$ 6$ million ( 1.5 percent of net assets of $\$ 400$ million). Under these circumstances, the adviser could increase its fee by another $\$ 1$ million simply by borrowing another $\$ 100$ million and investing in real estate assets, even if the additional assets showed no promise of yielding additonal income to the trust.

183 I BLue SkY LAw REP. (CCH) \4801.

184 As of the end of 1977, approximately 36 trusts had adopted an "expense only" method of compensating their advisers, representing the largest category of compensation arrangements between REITs and their advisers. The number would have been even larger save for the fact that at least 12 trusts formerly on an expense only basis had since shifted to self-administered status. National Ass'n of Real Estate Investment Trusts, REITs MONTHLX, at 7 (Apr. 1978).

185 For a discussion of the coverage and liability standard of each of the relevant statutes see notes 80-101 supra \& accompanying text. 
statutory fraud provisions under the 1933 and 1934 Acts.186 Indeed, in one case, the SEC instituted an action against a REIT adviser for failure to disclose allegedly "exorbitant" profit margins associated with the advisory fee it was receiving. ${ }^{187}$ Notwithstanding these considerations, however, comparatively few REIT advisers even now disclose costs or profits in connection with advisory services in public filings with the SEG or reports to REIT shareholders. ${ }^{188}$ For reasons to be articulated later, REIT trustees must be provided with such information if they are to participate effectively in advisory fee negotiations.

\section{Possible Statutory Approaches: An Examination of Sections 15 and 36 of the Investment Company Act}

For the most part, the problems associated with fee arrangements between REITs and REIT investment advisers parallel those presented by compensation arrangements between regulated investment companies and their advisers. The mutual fund, like the REIT, typically pays its adviser based on fund size, not on fund performance, thus creating incentives for the adviser to increase fund size through leverage or sales of additional shares, even though this may not benefit existing fund shareholders. In addition, the fund adviser, like the REIT adviser, typically dominates the affairs of the fund, controls the proxy machinery, and selects individuals to serve as "independent" directors on the fund's board. ${ }^{189}$ Finally, the fund adviser, like the REIT adviser, typically owns most of the operating assets of the fund and employs operating personnel, making dismissal of the adviser a difficult if not totally unrealistic bargaining alternative in the negotiation of fee arrangements.

186 See, e.g., John G. Kinnard \& Co., [1973-1974 Transfer Binder] FED. SEC. L. REP. (CCH) I 79,662 (1974). Cf. Commodity Management Serv. Corp., [19731974 Transfer Binder] Mur. Funds Gunde (CCH) 『 10,035 (1974) (failure to disclose an advisory fee that exceeds normal industry standards would violate the antifraud provisions of $\$ 206$ of the Investment Advisers Act, 15 U.S.C. $\$ 80 \mathrm{~b}-6$ (1976)); Mexico Fund, SEc. REg. L. Rep., July 30, 1975, at C-1 (fee of 1.5 percent of net asset value raises questions under Investment Company Act $\S 36(\mathrm{~b})$.

187 SEC v. Continental Advisers, Civ. No. 78-0066, (D.D.C., filed Jan. 16, 1978). See Securities \& Exchange Comm'n, Litigation Release No. 8257 (Jan. 16, 1978).

188 See REIT Compensation Plans 1976, supra note 171, at 37:

Unhappily, very few REITs are reporting to their shareholders on a regular basis the results of operations of their adviser. When this is done, it is usually contained in proxy statements supporting expense-only fees. Thus the REIT shareholder remains largely in the dark about how the dollars of advisory fees are actually being spent. Perhaps it will take some evolution toward greater maturity among REIT trustees to evaluate disclosure standards in this area.

180 See note 145 supra \& accompanying text. 
The Investment Company Act contains two principal provisions designed to mitigate the possibilities for self-dealing in the negotiation of investment advisory contracts between investment companies and external advisers. These are sections $15^{190}$ and 36..$^{191}$ An examination of the legislative development of both sections is necessary to an understanding of the current legal interpretations of each.

As originally enacted, section 15 (a) required that fund advisers serve pursuant to written contracts setting forth all compensation to be paid and that such contracts be initially approved by a majority of shareholders and approved at least annually thereafter by a majority of shareholders or directors. ${ }^{192}$ The duration of the advisory contract was limited to two years. ${ }^{193}$ Section 15 (c) further required that all modifications of advisory contracts be approved by a majority of shareholders or directors of the company. ${ }^{194}$ Under section 36 of the Act, the Securities and Exchange Commission was empowered to seek injunctive relief against directors or investment advisers for "gross misconduct or gross abuse of trust"; 195 neither section 15 nor 36 explicitly authorized private suits by shareholders against directors or advisers for excessive advisory fees.

The experience under both sections 15 and 36 proved to be largely unsatisfactory for several reasons. First, mere approval of advisory contracts by shareholders and directors was felt to be an inadequate safeguard against overreaching by investment advisers. ${ }^{198}$ Second, the Saxe v. Brady "waste of assets" standard effectively shielded advisory compensation schemes from judicial invalida-

19015 U.S.C. $\$ 80 \mathrm{a}-15$ (1976).

101 Id. $\$ 80 \mathrm{a}-36$. (1940).

192 Investment Company Act of 1940, ch. 686, $\$ 15(\mathrm{a}), 54$ Stat. 789, 812

193 Id.

$194 I d$. at $\$ 15(\mathrm{c}), 54$ Stat. at 813 .

$195 \mathrm{Id}$. at $\$ 36,54$ Stat. at 841 .

196 H.R. Rep. No. 91-1382, 91st Cong., 2d Sess. (1970) (memorandum of SEC):

Insofar as the shareholders are concerned the management company has control of the proxy machinery and there is never any contest over the management fee, with the result that the shareholders have no realistic choice except to send their proxies to representatives of the management company or not to vote at all. Like shareholders generally, they will, as a matter of routine, return their proxies if requested to do so by management.

Id. 87. See also Hearings before the Subcomm. on Commerce and Finance of the House Comm. on Interstate and Foreign Commerce, 91st Cong., 2d Sess., Ser. No. $91-34$, at 856 (statement of $\mathrm{H}$. Budge). 
tion. ${ }^{197}$ Finally, although certain courts held that sections 15 and 36 implicitly created a private cause of action in favor of aggrieved shareholders, ${ }^{198}$ others declined to hold that such actions existed. ${ }^{199}$

As a result of the foregoing factors, the SEC sponsored, and Congress in 1970 passed, a bill substantially modifying sections 15 and 36.200 The bill accomplished three significant reforms. First, it specified in section 15 (c) that the director of a fund has a duty to request and evaluate, and the investment adviser has a duty to furnish, "such information as may reasonably be necessary to evaluate the terms of any [investment advisory] contract." 201 These obligations are identical to the duties of disclosure, investigation, and consideration that the courts have enunciated in construing the section 36(a) fiduciary duty. ${ }^{202}$ Second, it replaced the "gross abuse of trust" standard under the prior section 36 with a broader standard allowing the SEG to seek injunctive relief against officers, directors, and investment advisers for any "act or practice constituting a breach of fiduciary duty involving personal misconduct." ${ }^{203}$ As previously indicated, ${ }^{204}$ the legislative history indicates that Congress intended that nonfeasance or negligence on the part of a fund director-in addition to misfeasance-would be actionable under the amended section. In enacting the more stringent standard of liability, Congress implicitly rejected the limited judicial scrutiny contemplated by Saxe in favor of a deeper inquiry into the fairness of an advisory contract. ${ }^{205}$ Finally, it created a new provision-sec-

197 See Nutt, supra note 146, at 93 (citing Kurach v. Weissman, 49 F.R.D. 304, 305-06 (S.D.N.Y. 1970)); Acampora v. Birkland, 220 F. Supp. 527, 548-49 (D. Colo. 1965); Meiselman v. Eberstadt, 39 Del. Ch. 563, 170 A.2d 720 (1961).

198 E.g., Brown v. Bullock, 194 F. Supp. 207 (S.D.N.Y.), aff'd, 294 F.2d 415 (2d Cir. 1961).

199 E.g., Brouk v. Managed Funds, Inc., 286 F.2d 901 (8th Cir.), vacated, 369 U.S. 424 (1961).

200 Investment Company Amendments Act of 1970, Pub. L. No. 91-547, 84 Stat. 1413,1429 (1970).

201 Section 15(c) provides in relevant part:

It shall be the duty of the directors of a registered investment company to request and evaluate, and the duty of an investment adviser to such company to furnish, such information as may reasonably be necessary to evaluate the terms of any contract whereby a person undertakes regularly to serve or act as investment adviser of such company.

15 U.S.C. $\$ 80 \mathrm{a}-15$ (1976).

202 For a discussion of the content of this duty of disclosure, and a comparison with its common law counterparts, see notes 116-36 supra \& accompanying text. 203 Section 36(a), 15 U.S.C. $\$ 80 a-36 a$ (1976).

204 See note 133 supra.

205 See Galfand v. Chestnutt Corp., 545 F.2d 807, 811-12, (2d Cir. 1976), cert. denied, 435 U.S, 943 (1978). 
tion $36(\mathrm{~b})$-that imposed a specific fiduciary duty upon investment advisers with respect to receipt of compensation from registered investment companies, and further created a cause of action in favor of fund shareholders against advisers for breaches of the newly-imposed fiduciary duty. ${ }^{206}$

In principle, the application of provisions similar to those contained in sections 15(c) and 36(a) and (b) of the Investment Company Act to advisory contracts between REITs and their investment advisers would serve several salutary purposes. In the first instance, it would place an affirmative duty upon investment advisers to disclose all relevant information in connection with contract reapproval and, more importantly, would impose a duty upon trustees to request and consider all such information. Under Saxe v. Brady, which presumably defines the current standard by which the fairness of REIT advisory contracts is to be judged, there is no ostensible requirement that such information be produced or considered in connection with ratification of advisory contracts by shareholders or directors. As was discussed previously, the requirements of disclosure, investigation, and consideration are much more stringent than their common law counterparts-the duties of loyalty and care. ${ }^{207}$ Second, such provisions would clearly impose fiduciary obligations upon the investment adviser with respect to the amount of fee compensation-obligations that may or may not now be incumbent upon the adviser under the common law. ${ }^{208}$ Finally, such provisions would reinforce the incentives of investment advisers to discharge their statutory duties by creating an express federal cause of action in favor of shareholders whose interests are adversely affected by unreasonable or excessive advisory compensation agreements.

206 Section $36(\mathrm{~b})$ provides, in relevant part:

(b) For the purposes of this subsection, the investment adviser of a registered investment company shali be deemed to have a fiduciary duty with respect to the receipt of compensation for services, or of payments of a material nature, paid by such registered investment company, or by the security holders thereof, to such investment adviser or any affliated person of such investment adviser. An action may be brought under this subsection by the Commission, or by a security holder of such registered investment company on behalf of such company, against such investment adviser, or any affiliated person of such investment adviser, or any other person enumerated in subsection (a) of this section who has a fiduciary duty concerning such compensation or payments, for breach of fiduciary duty in respect of such compensation or payments paid by such registered investment company or by the security holders thereof to such investment adviser or person ....

15 U.S.C. $\$ 80 \mathrm{a}-36 \mathrm{~b}(1976)$.

207 See text accompanying notes 116-36 supra.

208 See note 72 supra. 
Application to REITs of legislative provisions similar to sections 15 and 36 is not, however, without problems. As presently worded, there is some doubt as to whether section 36(a) creates a separate private cause of action in favor of mutual fund shareholders. Two commentators have suggested, ${ }^{209}$ and several courts have held, ${ }^{210}$ that section 36 (a) does not create a private right of action. The 1970 amendments to the Acts expressly created only one private cause of action-that afforded by section $36(\mathrm{~b})$-which only provides a remedy against investment advisers or other persons enumerated in section 36(a) who receive advisory compensation. ${ }^{211}$ Given the explicit language of section $36(\mathrm{~b})$, it has been argued that Congress intended to preclude private causes of action for breaches of the fiduciary duties imposed by sections 15(c) or 36(a) upon the officers and directors of registered investment companies. ${ }^{212}$ If this argument were accepted, shareholders could not hold fund directors liable for breach of their fiduciary duties with respect to approval of the advisory contract except in the fortuitous circumstance in which the directors were themselves recipients of advisory compensation. With respect to REITs as well as mutual funds, however, the existence of such a private cause of action against directors or trustees, irrespective of their receipt of compensation, would serve a valuable deterrent function. Accordingly, legislation directed at regulating REIT advisory fees should expressly create such a private cause of action..$^{213}$

The proposed legislation should avoid a second inadequacy of section 36(b). As previously noted, section 36(b) imposes a fiduciary duty upon investment advisers of registered investment companies with respect to advisory compensation; the legislative history of the section indicates that, consistent with this duty, the advisory fee must be "reasonable." ${ }^{214}$ The Investment Company Act does not, however, specify what constitutes a reasonable fee, what types of fee arrangements are inconsistent with the fiduciary duties imposed by

200 Crane \& Walker, supra note 114.

210 Brouk v. Managed Funds, Inc., 286 F.2d 901 (8th Cir. 1961), vacated, 369 U.S. 424 (1961); Monheit v. Carter, 376 F. Supp. 334, 342 (S.D.N.Y. 1974) ( $\$ 36(a)$, absent violations of other sections, creates no private cause of action).

211 Section $36(\mathrm{~b})(3)$ provides: "No such action shall be brought or maintained against any person other than the recipient of such compensation or payments, and no damages or other relief shall be granted against any person other than the recipient of such compensation or payments." 15 U.S.C. $\S 80 a-35$ (1976).

212 See R. Pozen, Financlat Instimutions: Investadent Management 272-73 (1978); but see Freedman \& Rosenblat, Duties to Mutual Funds, 4 Rev. SEc. REG. 937 (1971).

213 See text accompanying note 235 infra.

2141970 Mutual Fund Amendment Hearings, supra note 145, at 188-89. 
section $36(\mathrm{~b})$, or what factors are relevant in connection with such a determination. In the original bill that culminated in the $\mathbf{1 9 7 0}$ amendments to the Investment Company Act, the SEC specified a number of factors to be considered in determining the reasonableness of an advisory fee. ${ }^{215}$ The final version of the bill passed by Congress did not refer to these or to any other factors in connection with evaluation of the advisory fee. Moreover, the only cases decided under the amended sections 15 (c) and 36(a) and (b) have involved the limited issue of fund-directed recapture of brokerage commissions; ${ }^{216}$ in the eight years since the passage of the 1970 amendments to the Act, no case has articulated the factors that fund directors should consider in connection with the evaluation of the reasonableness of advisory fees.

Section 15 (c)'s general requirements of investigation and consideration of relevant information do not provide a useful directive to trustees or directors who may have only minimal knowledge of the economic and financial factors that shape the terms of the advisory contract. As Circuit Judge Moore once observed, the "paths of rectitude" that directors are required to follow in approving advisory contracts are paths "which neither Congress nor the courts have laid out with such markers as may be easily discernible by the pedestrian director." ${ }^{217}$ At a minimum, legislation seeking to ensure informed and considered scrutiny of the fairness of an advisory compensation scheme should provide an express indication of the factors to be considered. In connection with the approval of advisory contracts between a REIT and its adviser, there are two critical factors that should be statutorily-required

215 These factors included: (1) the nature and extent of the services provided to the fund; (2) the quality of the services rendered; (3) the economies of scale attributable to fund growth; (4) the cost of comparable services delivered by other externally and internally managed funds; and (5) the value of benefits other than the advisory fee received by the fund. 1970 Mutual Fund Amendment Hearings, supra note 145 , at 188 .

216 E.g., Tannenbaum v. Zeller, 552 F.2d 402 (2d Cir.), cert. denied, 434 U.S. 934 (1977); Galfand v. Chestnutt Corp., 545 F.2d 807 (2d Cir. 1976), cert. denied, 435 U.S. 943 (1978); Moses v. Burgin, 445 F.2d 369 (1st Cir.), cert. denied, 404 U.S. 994 (1971).

217 Brown v. Bullock, 294 F.2d 415, 425 (2d Cir. 1961) (Moore, J., dissenting). See also R. Jennings \& H. Marsh, Securtites Regulation 1537 (3d ed. 1972) (the "reasonableness" standard of $\$ 36(\mathrm{~b})$ "is a lesson in the art of studied ambiguity in drafting of statutes").

As Justice Franlfurter once observed:

[T]o say that a man is a fiduciary only begins analysis; it gives direction to further inquiry. To whom is he a fiduciary? What obligations does he owe as a fiduciary? In what respect has he failed to discharge these obligations? And what are the consequences of his deviation from duty? SEC v. Chenery Corp., 318 U.S. 80, 85-86 (1943). 
items of disclosure, investigation, and consideration: ( 1 ) the costs and profits associated with the advisory company's operations; and (2) the economic performance of the REIT relative to that of similarly-situated REITs.

For several reasons, trustee scrutiny of the costs and profits associated with administration of the REIT is necessary in order effectively to evaluate advisory compensation arrangements. ${ }^{218}$ First, if the adviser's profit margin is substantially higher than profit margins earned by other REIT advisers performing similar services and achieving comparable investment returns, the REIT may be able to increase earnings by securing the services of another investment adviser. Alternatively, if, as was apparently the case in 1972$74,{ }^{219}$ the profit margins of all REIT advisers are uniformly high, the REIT may simply choose to become self-administered, thus eliminating as a cost the substantial profits that would otherwise go to the adviser. Third, if profits earned by advisers are uniformly high vis-à-vis rates of return for business enterprises with comparable degrees of risk, disclosure of such profits should encourage market entry by other advisers, thus reducing the level of advisory fees charged to all REITS; if excessive advisory profit margins remain a well-kept secret, the market mechanism will not operate to increase competition or reduce fees. Finally, and most significantly, as a REIT's portfolio increases in size, it is probable that the adviser will experience significant economies of scale with respect to administrative costs. This, in turn, will yield substantially higher profits for the adviser if the base fee continues to increase proportionately, as administrative costs increase at a much slower rate. Hence, a fee based on one percent of the size of the portfolio may yield a normal profit on a $\$ 100$ million portfolio, but an unreasonably high profit on an $\$ 800$ million portfolio. ${ }^{220}$ If a

218 At least one other commentator has suggested the appropriateness of disclosure of advisers' profit margins in connection with evaluations by trustees directors of advisory contracts. Kraut, supra note 22, at 53. See also Mundheim \& Nutt, The Independent Directors of Mutual Funds, 6 Wharton Q. 8, 23-24 (1972) (suggesting disclosure of advisers' cost and profit figures to mutual fund directors).

219 See notes 154-56 supra \& accompanying text.

220 Similar concerns were voiced by the SEC in its 1966 report on investment companies:

The Wharton Report found that as of 1960 most investment advisers were not sharing the economies of size with the funds and their public shareholders. In approximately four out of every five cases mutual fund advisory fee rates were fixed and did not vary with the size of the assets managed. Annual fees "tended to cluster heavily around the traditional rate of 0.50 percent of average net assets."

Because of the absence of competition, the limitations of disclosure, the ineffectiveness of shareholder voting rights and the difficulty of effec- 
REIT's independent trustees are to adequately assess the effect of portfolio growth and the accompanying economies of scale in evaluating the fairness of an advisory contract, it is reasonable-indeed, imperative-that they be furnished with data indicating the amount of the adviser's operating costs and profits as portfolio size increases. $^{221}$

It may, however, be argued that adequate market mechanisms exist to regulate the size of advisory fees without disclosure of profit margins. At any given time, there are a number of REITs in the marketplace in which an investor may choose to invest. Each has a record of return on equity. If the advisory fee is too high compared with that charged by other REIT advisers with similar performance records, the return on equity will be lowered vis-à-vis that of other REITs, forcing down the price of that REIT's equity shares and impairing its ability to obtain funds through new equity offerings. A significant restriction of the REIT's ability to expand portfolio size would in turn limit the adviser's ability to increase its profits through the receipt of higher fees.

This argument has validity, however, only if REITs are limited to capital expansion through new equity offerings, which is clearly not the case. If, as was the case in 1972 to 1974, portfolio expansion is effected largely through debt leveraging, ${ }^{222}$ the market price of equity shares may be of secondary importance to further expansion and may not provide an incentive to keep advisory fees low. More significantly, the differences in return on equity by virtue of disparate advisory fees may not have a sufficiently material impact on return on equity to affect the price of a REIT's equity shares. Hence, given a sufficiently large base of earnings and shareholder equity, a REIT adviser may increase its fee and profit margin by a

tive action by unaffliated directors, advisory fee rates did not decline as the funds grew. With some exceptions, it was the pressures generated by the publication of the Wharton Report and the pendency of shareholder litigation that led to such departures as there have been from the traditional flat fee rate of 0.50 percent. These departures have seldom been substantial.

Public Policy Implications, supra note 145, at 11-12 (footnotes omitted). See also id. 94-108.

221 In apparent recognition of the economies of scale associated with the management of large portfolios, certain REIT advisory contracts have called for a reduced base fee as a percentage of portfolio as portfolio size increases. However, as of 1976, of 138 mortgage, equity, and hybrid REITs surveyed by Audit Investment Research, only 21 had such arrangements with their advisers. REIT COMPENSATron Plans, 1976, supra note 171, at 41-53.

222 See notes 255 \& 256 infra \& accompanying text. 
significant amount with only a relatively insignificant negative impact on income and total return on equity. ${ }^{223}$

The second factor that is significant in evaluating the reasonableness of the advisory fee arrangement is the relative quality of the management services rendered. A management fee and profit margin of a REIT adviser that are substantially higher than those earned by other REIT advisers may be justified if the investment performance attributable to the adviser is superior to that of other REITs; conversely, an inferior performance may counsel a lower fee and profit margin. If a REIT does not achieve at least average performance compared with similarly-situated REITs, the trustees should expect the investment adviser to explain why and to outline the steps being taken to improve performance.

Congress and the SEC have given recognition to the equities of the general proposition that fees should reflect unfavorable as well as favorable investment performance through regulation of incentive fee arrangements between regulated investment companies and their investment advisers. Under section 205(1) of the Investment Advisers Act of $1940,{ }^{224}$ Congress specifically prohibited compensation arrangements between investment advisers and their clients based in whole or in part upon capital gains or capital appreciation unless such arrangements provided for upward and downward adjustment of the fee to reflect comparative performance of the fund with the market as a whole. In so doing, the legislation reflected

223 This may be illustrated as follows. Suppose a REIT has a total portfolio of $\$ 500$ million, shareholders' equity of $\$ 250$ million, and income of $\$ 30$ million before deduction of the advisory fee. Suppose that the advisory fee is one percent of the total portfolio size. Under these circumstances, the REIT's earnings are $\$ 25$ million, representing a 10 percent return on equity.

If the adviser raises its fee to 1.2 percent of portfolio, all else being equal, the total advisory fee becomes $\$ 6$ million-a 20 percent increase in income-but the REIT's earnings decline to $\$ 24$ million, only a 4 percent decrease. Total return on equity, moreover, declines from 10 percent to 9.6 percent, a decrease of 0.4 percent. The increase in the fee, on a per share basis, may be negligible, though the increased return to the adviser is quite significant.

In this context, with respect to mutual fund advisory contracts, the following pertinent observation has been made:

Another argument made was that fees that may look large in the aggregate are really small. After all, one-half of 1 percent on a $\$ 5,000$ investment is only $\$ 25$ a year. . . . Such an argument is sheer sophistry, of course, because even the most outrageously exorbitant fees or charges can be made to sound "reasonable" if they are spread over a very large group. In this argument the industry, which wishes to use the fund's corporate form to exact such high fees, now wishes to divide the fee by the hundreds of thousands of shareholders when we examine the fees closely.

1970 Mutual Fund Amendment Hearings, supra note 145, at 858 (statement of H. Budge).

22415 U.S.C. $\$ 80 \mathrm{~b}-5$ (1976). 
the congressional concern that incentive fees based upon realized return would encourage undue risk-taking by investment advisers without an appropriate penalty for substandard performance when measured against market performance. ${ }^{225}$ Accordingly, section 205 specifically requires that any compensation arrangement based upon net asset value proportionately increase and decrease in relation to an appropriate index of securities prices. ${ }^{226}$

Significantly, incentive fee arrangements contained in most REIT advisory contracts do not incorporate the upward and downward fee adjustment provisions required in mutual fund advisory contracts under section 205(1) of the Investment Advisers Act. As of 1976, almost all REIT advisory contracts surveyed incorporated incentive fee arrangements. ${ }^{227}$ These arrangements typically awarded a stated percentage of all income to the advisers over and above an amount representing a base return on equity; they contained no penalty, however, if income failed to attain the specified base return. ${ }^{228}$ As a result, these types of fee arrangements tend to reward excessive risk-taking by an adviser if investments produce high returns, but impose no concomitant fee penalties if high-risk investment policies yield substandard results.

At a minimum, regulatory legislation directed at REITs and REIT advisers should require upward and downward fee adjustment provisions if performance fees are a part of the advisory contract. This is consistent with the congressional concerns embodied in section 205(1) of the Investment Advisers Act. In addition, however, such legislation should go a step beyond mere regulation of incentive fees, and statutorily mandate consideration of investment performance by independent trustees in connection with all advisory contracts, not merely those that contain explicit incentive

225 H.R. Rep. No. 91-1382, 91st Cong., 2d Sess. 41 (1970); Securities \&

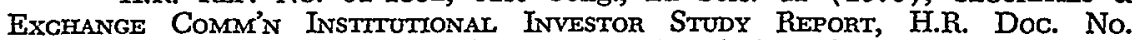
92-64, 92 Cong., 1st Sess. xiv-xv (Summary Volume) (1971) [hereinafter cited as INSTITUTIONAL INVESTOR STUDY].

226 See H. Bines, The Law of Investment Management 5-47 (1978). See generally Fink, Performance Fees, 5 Rev. SEc. REG. 829 (1972); Jansson, Whatever Happened to Performance Incentive Fees, 8 INSTTTUTIONAL INVESTOR 101 (1974); Kennedy, The Uses and Abuses of Performance Measurement, 7 INSTItutTonal Investor 60 (1973); Manges, The Investment Company Amendments Act of 1970-An Analysis and Appraisal After Two Years, 14 B.C. IND. \& CoM. L. REv. 387, 402-09 (1973).

227 REIT COMpensation Plans, 1976, supra note 171, at 43-53.

228 See text accompanying notes 160-63 supra. A second, though less common, incentive fee arrangement awards the adviser a fixed percentage of net capital gains realized by the REIT. Under these incentive arrangements, again, it appears that no penalty is imposed on the adviser if the REIT realizes net capital losses. REIT Compensation Plans, 1976, supra note 188, at 43-53. 
fee provisions. Adoption of such a standard would accomplish two important policy objectives.

First, a requirement that a REIT or mutual fund disclose its risk-adjusted performance in relation to a meaningful performance index and that such performance be considered in connection with advisory fee negotiations could represent a significant means to lessen the conflicts of interest inherent in fee structures that are based solely on portfolio size. If portfolio performance becomes a significant consideration in fee negotiations, the incentive to increase size through excessive debt leverage and/or the recommendation of high-risk investments may be significantly tempered if such policies unduly jeopardize earnings performance vis-à-vis that of other REITs.

Second, the use of risk-adjusted income performance encourages the trustees to reward superior investment and managerial performance and to penalize substandard performance; substandard performance by a REIT is indicative of poor investment advice and should be reflected in a commensurately lower advisory fee. If, on a comparative basis, the performance of the REIT is consistently substandard, consideration should be given to retention of another adviser or internalization of the advisory function. ${ }^{229}$

The use of relative risk-adjusted performance ${ }^{230}$ as a factor in evaluating the reasonableness of the REIT advisory fee is not,

229 The idea that relative risk-adjusted performance should be an item of required disclosure by mutual fund advisers has been endorsed by several commentators. In its 1970 study of mutual funds and other institutional investors, the Twentieth Century Fund advanced the following related suggestion:

If potential investors were provided with "full disclosure," they would be aware of the performance and costs of the fund offered to them compared with the broad alternatives, including other load funds, no-load funds, and closed-end investment companies (the latter frequently selling at a discount). This is another approach to more effective price competition in the setting of sales charges, one not considered by the SEC in its 1966 report on investment companies. To implement this approach the SEC might prescribe a way of presenting information on the front page of the prospectus (and in some suitable part of the annual report) comparing the performance and costs of the fund, over as long a period as feasible, with the corresponding group averages for other load funds, no-load funds, closed-end companies and the overall market performance weighted by the portfolio composition of the fund in question or otherwise adjusted for differences in portfolio risk.

I. Frnend, Mutual Funds and Other Institutional Investors: A New PerspeCTIve 105 (1970). See also Note, Mutual Funds and Their Advisers: Strengthening Disclosure and Shareholder Control, 83 YALE L.J. 1475, 1483-84 (1974), reprinted in $\mathrm{R}$. PozEN, supra note 212, at 333-34.

230 For the purposes of this Article, the term "risk adjustment" refers to the $\$ 205$ requirement that the performance of a fund be compared with "an appropriate index of securities prices." 15 U.S.C. $\$ 80 \mathrm{~b}-5$ (1976). See note 231 infra. As one commentator has critically observed, this standard provides only a "qualita- 
unfortunately, without pitfalls. Diversified mutual funds may be readily compared to a variety of performance indexes reflecting movement of market price and/or the performance of other mutual funds. ${ }^{231}$ Relative performance may be easily established since portfolio securities are frequently liquid and are traded in sufficient volume to establish an objective market price; these values may in turn be compared to indexes also comprised of securities whose values are readily ascertainable. REIT portfolios, by contrast, whether comprised of mortgages, real estate, or some combination thereof, are substantially less liquid; hence, they are less susceptible to objective market valuation and comparison. More significantly, difficult questions would arise as to the appropriateness of a given index as a method of comparing relative performance. REITs differ substantially in terms of degree of portfolio diversification, type of portfolio asset, and degree of debt leverage. For example, it would make little sense to compare the performance of a REIT that invested principally in FHA-secured residential mortgages with little or no leverage, with that of another REIT whose portfolio was comprised of high-risk construction and development mortgages or equity interests. Because of the greater degree of risk associated with the investments made by the second REIT, one would expect a higher rate of return than that produced by the first, and such a comparison would presumably be "inappropriate" for purposes of section 205. ${ }^{232}$ The example does, however, provide an intimation of the problems that could arise in the course of the "appropriateness" inquiry when variables such as portfolio diversification and degree of leverage complicate the situation.

These problems are not insuperable, however. Merely because the value of a portfolio consisting of real estate or real estate-secured mortgages is more difficult to determine than portfolios consisting of debt and equity securities does not mean that valuations cannot

tive" measure of risk adjustment-not the more intricate calculus required by capital market theory. Note, supra note 229, at 1479-82. Development of a theoretically valid risk adjustment mechanism is beyond the scope of this Article.

For a general discussion of the concept of risk adjustment of investment portfolios for comparative purposes, see BxNEs, supra note 226, at 5-49 to 5-50; Cohen, The Suitability Rule and Economic Theory, 80 Yaxe L.J. 1604, 1607-11 (1971). 231 See, e.g., Arthur Lipper Corporation Indexes (published weekly in BARRoN's). This does not mean that a performance index may be indiscriminately established: the index must reflect performance of funds that are similarly situated or of securities of the type comprising the investment company's portfolio. See Securities \& Exchange Comm'n, Investment Advisers Act Release No. 315 (Apr. 6, 1972), [1971-72 Transfer Binder] FEd. SEc. L. Rep. (CCH) đ78,694. See also Mexico Fund, SEc. Reg. \& L. Rep. (BNA) at C-I (July 30, 1975); Hyperion Fund, Inc., [1973 Transfer Binder] Fed. SEc. L. REP. (CCH) I7 79,315.

232 See note 231 supra. 
be made or that comparisons of relative performance are invalid. As previously indicated, ${ }^{233}$ a number of REITs utilize incentive compensation arrangements predicated upon returns on shareholders' equity. Given the large numbers of REITs in existence, it should be possible to determine the average returns on equity for REITs with similar portfolios and investment objectives and to make valid comparisons between the performance of an individual REIT and the appropriate index. To the extent return on equity failed to reflect unrealized portfolio gains, appropriate adjustments could be made where such gains could be adequately substantiated through current independent appraisals or analyses. ${ }^{234}$

\section{Recommendation}

Given the considerations outlined herein, any legislative approach to regulation of REIT advisory fees should, at a minimum, accomplish two things. First, it should impose a fiduciary duty upon the investment adviser to disclose, and upon the nonaffiliated trustees to consider, all factors relevant to an evaluation of the reasonableness of the advisory fee arrangement. Second, it should provide at least minimal guidance to those individuals concerning the types of factors relevant to an evaluation of the fee arrangement.

The fiduciary concepts that are the underpinnings of sections 15 and 36 of the Investment Company Act represent a fundamentally sound approach to regulation of compensation arrangements between REITs and their investment advisers. The provisions do not place artificial limitations on investment advisory contracts as do the current limitations utilized by the MSCA. Rather, they place the burden on those individuals best-situated to evaluate and negotiate the most favorable arrangements for the REIT-the

233 See note 226 supra \& accompanying text.

234 Generally speaking, financial accounting principles do not permit recognition of increases in market value of assets short of sale or other disposition of the asset. Such gains will typically occur in connection with real estate interests acquired by equity and hybrid REITs, although mortgage REITs may also experience capital appreciation if prevailing interest rates for comparable investments fall below the actual rates of interest at which the REIT has extended loans. To the extent that reported net income-hence, return on equity-fail to reflect such increases, adjustments in income can and should be made to present a more realistic comparative picture of the investment performance of the REIT. Adoption of a measure of "current value" accounting by REITs is not a revolutionary proposition. A 1975 AICPA proposal advocated that REITs be required to calculate alowances for losses on loans and foreclosed properties utilizing an estimate of "recoverability" of the collateral property. Accounting Standards Drviston, amerucan Institute of Certified Public Accountants, Statement of Posttron on Accounting Practices of Reat Estate Investment Trusts 2, 6 (June $27,1975)$. A necessary step in the recoverability calculation is valuation of the underlying property. Id. $4-5$. 
REIT trustees. In addition, like the Investment Company Act, the creation of a private cause of action should provide an effective means of enforcement of this provision as well as redress for aggrieved REIT shareholders. Specifically, this Article has suggested that such legislation should create a cause of action against REIT trustees as well as investment advisers for failure to discharge their respective fiduciary obligations. As previously indicated, this is not altogether clear under current provisions of the Investment Company Act. ${ }^{235}$

The principal inadequacy of the Investment Company Act is its failure to articulate more clearly the factors that are relevant to the evaluation of advisory compensation agreements. It is suggested that any legislation dealing with regulation of REIT compensation arrangements must include a minimum specification of the factors to be disclosed to and considered by the REIT's nonaffiliated trustees in reaching this determination, including: (1) a detailed description of the costs and profits associated with administration of the REIT; and (2) a comparison of the REIT's investment performance with that of a meaningful index of performance of other similarlysituated REITs.

\section{Regulation of Risk Taking}

\section{A. Background}

The final area in which the regulatory concerns embodied in the Investment Company Act apply to REITs is that of the regulation of investment risk-taking. The Investment Company Act restricts the amount of risk allowable to a regulated investment company principally through restrictions on debt leverage. Specifically, section 18 of the Act ${ }^{236}$ prohibits the issuance of senior securities or bonds by open-end investment companies, ${ }^{237}$ and allows borrowings from banks by open and closed-end companies (or the issuance of senior securities or bonds by closed-end companies) to the extent that the fund's assets exceed total bank debt by specified percentages. ${ }^{238}$

235 See notes 209-12 supra \& accompanying text.

236 I5 U.S.C. $\$ 80 \mathrm{a}-18$ (1976).

237 Section 5 of the Act divides management companies (defined in $\$ 4$ ) into "open end" and "closed end" companies. An "open end" fund is one that issues new shares or has outstanding redeemable securities that it has issued. 15 U.S.C. $\$ \S 80 \mathrm{a}-4,80 \mathrm{a}-5$ (1976).

238 See text accompanying note 262 infra. Although not relevant to the present inquiry, $\$ 12(a)$ of the Act and the interpretive releases thereunder place further restrictions on risk-taking by regulated investment companies through restrictions on margin purchases of securities and, except in specified instances, short sales. 15 U.S.C. $\$ 80 \mathrm{a}-12(\mathrm{a})(1976)$. 
At present, REITs are not subject to comparable regulatory restrictions on debt leveraging or, for that matter, any other form of risk-taking. The declarations of trust of a number of REITs contain limitations on the maximum amount of borrowings, designated as a multiple of net assets, which the REIT may incur. These limitations, however, tend to be extremely liberal, permitting total borrowings/net asset multiples of from 300 to 800 percent. ${ }^{239}$ The current MSCA statement provides that the aggregate borrowings of the trust shall not be "unreasonable" in relation to the trust's net assets, as defined; the statement provides no guidance, however, concerning what constitutes an unreasonable degree of debt leverage. ${ }^{240}$ The federal securities laws contain no affirmative restrictions on risk-taking by REITs apart from the general disclosure requirements of the Securities Act of $1933^{241}$ and the Securities Exchange Act of 1934.242 The restrictions imposed by section 23 of the Federal Reserve Act ${ }^{243}$ on national banks respecting loans to affiliates have not been construed to apply to loans by banks to REITs that they sponsor and advise, even though such restrictions were designed to mitigate excessive risk-taking of precisely the type that has occurred between banks and bank-sponsored REITs. ${ }^{244}$

The unique management structure of the REIT creates special incentives, typically absent in other forms of business enterprise, to engage in risk-taking through excessive debt leveraging. As previously discussed, the fee structures of most REITs have been (and in many cases still are) based upon the total size of the REIT's investment portfolio, including funded as well as unfunded commitments. ${ }^{245}$ Thus, the REIT's adviser may increase the size of the fee by increasing the REIT's outstanding debt, and thereby inflate the number of outstanding loan commitments for purposes of fee determination. Advisory contracts that contain an additional incentive provision based on earnings in excess of a defined amount, and omit a concomitant penalty clause based on substandard earnings, create an additional incentive to engage in excessive risk-

239 See Appendix C.

240 Subsection $D$ of the MSCA statement provides, in full: "Leverage. The aggregate borrowings of the trust, secured and unsecured, shall not be unreasonable in relation to the net assets of the trust, as defined in paragraph $\mathrm{C}$ hereof, and the maximum amount of such borrowings in relation to the net assets shall be stated in the prospectus. 1 BLUE SKX L. ReP. (CCH) 【4801.

24115 U.S.C. $\$ \$ 77 \mathrm{a}-77 \mathrm{bbbb}(1976)$.

242 Id. $\$ \$ 78 \mathrm{a}-78 \mathrm{kk}$.

24312 U.S.C. $\$ 371$ (c) (1976).

244 See notes 284-86 infra \& accompanying text.

245 See notes 157-59 supra \& accompanying text. 
taking through leverage and the recommendation of high-risk investments. As previously indicated, many REIT advisory contracts currently contain such incentive provisions. ${ }^{246}$

The requirements of the Internal Revenue Code create even further incentives to leverage. Under section $857(\mathrm{a})(1),{ }^{247}$ in order to qualify for tax-exempt status, a REIT must distribute to shareholders at least ninety percent of its total income on an annual basis. As a result, the REIT is precluded from building substantial retained earnings as a basis for further expansion and must instead resort to debt leverage or new offerings of equity to generate funds for further expansion. And, although the use of equity offerings creates a more favorable debt-equity ratio for the REIT, expansion through periodic equity offerings may require substantial interim increases in the REIT's debt, thus increasing the debt-equity ratio. ${ }^{248}$

A final factor contributing to the incentive to leverage REITs relates to the incidence of sponsorship of REITs by financial institutions, especially commercial banks. As of the end of 1974, thirty-nine REITs, representing almost one-third of total industry assets, were advised by commercial banks or subsidiaries of commercial banks. ${ }^{249}$ These banks, in turn, provided massive credit facilities, including lines of credit and term and revolving loans, to the REITs that they sponsored.250 The incentives to loan heavily to

246 See note 227 supra \& accompanying text.

247 I.R.C. $\$ 857(\mathrm{a})(1)$. For tax years ending after 1979, the income distribution requirement is raised to $95 \%$.

248 It is advantageous for a REIT to offer new equity shares only if the price of those shares exceeds the book value of existing shares. Otherwise, a new equity offering will lower the book value of existing shares. To maintain a share price in excess of book value, however, it is necessary consistently to increase earnings and dividends. To effect this performance, the REIT must consistently increase the size of its portfolio-an increase that is often financed through additional borrowings. As one commentator has observed:

[T] he most important force [behind the rapid use of leveraging] . . . was

the constant pressure to increase earnings per share, quarter by quarter.

This was because consistent eamings and dividends were vital to keeping

the share price over book value. And only trusts with share prices over

book value could raise new capital-since the trust cannot add to perma-

nent capital by retaining earnings.

REIT Hearings, supra note 18, at 26. For a more comprehensive explanation of the debt-equity cycle, see Note, Real Estate Investment Trusts: A Current Assessment, 39 BROOKLYN L. Rev. 590, 602-03 (1973). 1975.

249 National Ass'N of Real Estate Investment Trusts, REIT Factbook,

250 Although no data have been collected indicating the size of borrowings by all REITs from their sponsor banks, selected instances suggest that the amounts are sizable. Hence, as of 1976, Chase Manhattan Corporation had loaned approximately \$142 million, an amount approaching the bank's legal loan limit, to Chase Manhattan Mortgage and Realty Trust, and Bankers Trust had advanced 
the REITs that they sponsored were several. First, as previously described, the banks could derive higher advisory fees as the size of the REIT's portfolio expanded in response to greater debtfinanced investment opportunities. ${ }^{251}$ Second, the issuance of loan commitments to the REIT provided immediate income to the sponsor bank with little or no corresponding cost; ${ }^{252}$ in the event that the loan commitment was actually funded, the bank also earned interest on the funded balances. Third, laws that effectively prevented commercial banks from extending certain types of loans could be circumvented if the loans were made by the bank's REIT, thus allowing the bank to offer otherwise prohibited financing to its good customers. ${ }^{253}$ Finally, banks that sponsored and financed REITs often derived income from balances maintained by the REIT and its borrowers with the bank as well as from the advantages of "float" on substantial checking transactions by the REIT. ${ }^{254}$

$\$ 75$ million, representing 55\% of the trust's bank financing, to BT Mortgage Investors. Subsidiaries of Fidelcor, Inc., a bank holding company, had, as of November 1977, \$41 million in outstanding loans to Fidelcor Growth Investors, representing nearly half of that trust's institutional borrowings. Other banks have acquired large amounts of assets from their REITs in return for reductions of outstanding debts from the REITs to their sponsor banks, including Continental Illinois Corporation ( $\$ 62$ million) and Hartford National Corp. ( $\$ 15-20$ million). See REIT Hearings, supra note 18, at 28 (statement of $\mathrm{K}$. Campbell); Fidelcor Growth Investors, Annual Report on Form 10-K (Year Ended Nov. 30, 1977), at F-9.

251 See notes 168-69 supra \& accompanying text.

252 As one expert observed:

In the boom days of 1971-73, the REITs were earning handsome profits writing standby commitments for each other's projects. The standby commitment is essentially a blank check in which a REIT or other lender agrees to fund a mortgage loan, often on onerous terms, if the developer is unable to borrow anywhere else when a building is completed. Such fees dropped almost immediately to the bottom line in most REIT accounting until rules were changed last year. At the same time banks were issuing a parallel volume of so-called back-up line commitments which REITs then used to support sale of commercial paper. They were especially helpful in allowing BHCs [bank holding companies] to earn handsome profits, which again dropped to the bottom line, without using any funds.

REIT Hearings, supra note 18, at 27 (statement of $\mathrm{K}$. Campbell).

253 Sponsoring a REIT enables a commercial bank to bypass indirectly a number of restrictions which may hamper its acquisition and lending of funds. For example, during the past tight money period a REIT could sell commercial paper without an interest rate ceiling, while banks were subject to such ceilings. Thus, a bank may want to sponsor a REIT in order to assure its customers of a source of real estate funds.

Schulkin, Recent Developments in the REIT Industry, NEW ENGLAND ECON. REv. 10 (September-October 1972).

254 "For example, if a trust was lending $\$ 20$ million to a contractor, and a check was issued on the adviser's bank on Friday, the check mightn't clear until the following Wednesday, giving the bank six days of interest on the check's "float." Falling Out: Real Estate Trusts Feud With Advisers Over Their Obligations, Wall St. J., March 13, 1975, at 1, col. 6. 
The tremendous incentives to engage in debt leveraging were reflected in the debt-equity structures of most REITs prior to the 1974 to 1975 collapse of the real estate market. Between 1971 and 1974, the year-end leveraging ratios of REITs increased as follows: 1971-51 percent, 1972-105 percent, 1973-161 percent, 1974 (June) -169 percent. ${ }^{255}$ From 1972-74, assets of the largest 134 REITs increased by 135 percent; during this same period, however, the increase in bank debt of the industry increased by 970 percent. ${ }^{256}$

The largest debt-equity ratios were incurred by the short-term mortgage REITs. Between June 1972 and June 1974, although gross income for the fifty-eight largest short-term mortgage REITs more than doubled ( $\$ 2.5$ million to $\$ 5.7$ million), interest expenses for non-convertible debt increased by over six times $\$ \$ 627,000$ to $\$ 4$ million). ${ }^{257}$ During this same period, while total income for short-term REITs more than doubled, the percentage of net income distributed to shareholders declined from nearly fifty percent to only two percent. Simultaneously, interest expense on non-convertible debt increased from about twenty-five percent of gross income to over seventy percent. ${ }^{258}$

The highly-leveraged posture in which most REITs found themselves when the real estate market collapsed in 1974-1975 contributed heavily to the collapse of the REIT industry itself. Reduced income from borrowers unable to meet interest payments, as well as large additions to loss reserves reflecting reduced collateral values, squeezed REIT earnings badly enough; in addition, the large debt service on loans to REITs from banks, as well as the increasing interest rates that accompanied the escalation of the prime rate, placed an intolerable burden on many REITs. As a result, many REITs were forced to renegotiate terms of outstanding bank loans, in many cases substantially extending maturity dates and reducing interest rates. ${ }^{258}$ Those REITs that had leveraged to the greatest degree were among the worst performing trusts during this

255 Securities \& Exchange Comm'n, Real Estate Investment Trusts: A Background Analysis and Recent Industry Developments, 1961-1974, at 21 (Economic Staff Paper, February 1975). Figures represent the ratio of the sum of short-term debt (commercial paper, bank loans owed, and credits) to the sum of equity shares plus convertible debentures outstanding.

256 REIT Hearings, supra, note 18, at 40-42 (statement of B. Neuberger).

257 Neuberger \& Hughes, Operating Performance of Short Term Trusts, 1972 74, REIT REVIEW, February 1976, at 1 .

258 REIT Hearings, supra note 18 , at $78-79$ (study by $B$. Neuberger and $M$. Hughes).

250 Id. 304 (report by Drexel Burnam \& Co., Inc.). 
period.260 According to one study that identified the impact of a series of factors on REIT profitability, the higher the percentage of nonconvertible debt to total capital, the worse the performance of the trust. ${ }^{261}$

\section{B. Regulation of Risk in REITs: Limitations on Debt Leverage}

The tremendous inducements to engage in excessive leveraging, as well as the disastrous experience of REITs with excessive debt leveraging, suggest that regulatory precautions are in order. Direct controls upon debt leverage modeled after those imposed by the Investment Company Act represent the most straightforward approach to the problem; that approach, however, is not without major drawbacks.

As previously indicated, ${ }^{262}$ section 18 of the Investment Company Act ${ }^{263}$ imposes stringent limitations on risk-taking by regulated investment companies, principally through limitations on debt leveraging. These limitations effectively restrict the type as well as the amount of debt that an investment company may incur. Specifically, section 18 (f) limits borrowings by open-end companies to bank loans, and then only to the extent that such loans are covered by assets representing at least 300 percent of the value of such debt. ${ }^{264}$ Under section 18(a), by contrast, closed-end companies may issue senior securities including bonds and preferred stock, but only if asset coverage represents 300 percent of the value of outstanding bonds and 200 percent of the value of outstanding preferred stock. 205

The legislative history of section 18 suggests that inclusion of the section was prompted by two concerns. The principal concern was that excessive leveraging would create an increased risk of bankruptcy in the event of market downswings. The SEC's Investment Trust Study purported to find a strong relationship between leverage and mutual fund performance. ${ }^{266}$ The Commission concluded that this negative relationship created a degree of risk with respect to securities of investment companies that was inconsistent

260 REIT FACTBOoK, supra note 1 , at 34-41.

261 REIT Hearings, supra note 18, at 63-64 (study by B. Neuberger and M. Hughes).

262 See note 236 supra \& accompanying text.

26315 U.S.C. $\$ 80 \mathrm{a}-18$ (1976).

264 Id. $\$ 80 \mathrm{a}-18(\mathrm{f})$.

205 Id. $\$ 80 \mathrm{a}-18(\mathrm{a})$. Section $18(\mathrm{~h})$ defines "asset coverage." Id. $\$ 80 \mathrm{a}-18(\mathrm{~h})$. 266 InvestMent Trust Studx, supra note 24 , at 478-79, 921-23. 
with the character of such companies.267 A subsidiary concern was the protection of holders of senior securities and bonds from conflicts of interest between their objectives and those of the holders of common shares. According to the SEC, the restrictions on issuance of senior securities and bonds would eliminate the undesirable conflicts in management objectives that are inherent in financial structures consisting of multiple classes of junior and senior securities and debt instruments. ${ }^{268}$

Consistent with these Congressional objectives, the regulation of risk-taking through direct limitations on debt leveraging has proven to be an effective means of insulating regulated investment companies from the effects of market downturns. Since 1940, the incidence of bankruptcy by regulated investment companies has been virtually nil. ${ }^{269}$ More significantly, this analysis suggests that, had REITs been subject to limitations similar to those of section 18 , many of the disastrous losses and perhaps all of the bankruptcies experienced by highly leveraged REITs could have been avoided. ${ }^{270}$

However, several factors militate against subjecting REITs to risk limitations similar to those imposed by section 18 . First, any statutory limitation on debt leverage will necessarily be largely arbitrary. The limitations imposed by section 18 apply to all regu-

207 Investment Company Act Hearings, supra note 24, at 1027-30. See also id. 265-66; Pubitc Policy Implications, supra note 145, at 65-67.

268 Spokesmen for the SEC during the hearings stated the following concerns:

We have found continual conflict between the senior and junior securities [of investment companies], where the junior securities are interested in appreciation and the senior securities are interested in safety. Yet the safety factor is entrusted to the very people who are interested in speculation.

Where you try to limit the number of different classes outstanding, try to legislate or regulate with respect to what protective features they should have, we say they should be like a mutual savings bank-one class of stock, no conflicts, everybody has a pari passu share in the voice of the management.

Investment Company Act Hearings, supra note 24, at 268-71 [statements of L. Smith \& D. Schenker].

269 Although there does not appear to be a definitive compilation of registered investment companies who have filed for reorganization under the Bankruptcy Act, a review of available records indicates that only six such companies have filed for bankruptcy since the passage of the Investment Company Act. These include: Central States Electric Corp., see In re Central States Electric Corp., 30 SEC 680 (1949); Selected Investments Trust Fund, Inc., see SEC, Corporate Reorganization Release No. 121 (May 12, 1959); First Home Investment Corp. of Kansas, see In re First Home Investment Corp., 308 F. Supp. 597 (D. Kan. 1973); Shamrock Fund, Inc.; Vanderbilt Growth \& Income Fund, Inc.; and All American Fund, Inc., see Letter from Richmond Pogue, Investment Company Institute, to William L. Martin (July 3, 1978) (on file with the University of Pennsylvania Law Review).

270 See REIT Hearings, supra note 18, at 96-97 (statement of R. Schotland). 
lated investment companies, irrespective of the types of assets in which the companies typically invest; thus, funds with the most conservative investment policies are subject to the same limitations on debt financing as the most aggressive and risk-oriented funds. Clearly, however, the liquidity and low degree of the risk associated with the investment securities of the former companies justify less stringent regulation of debt leverage than that which is appropriate with respect to the latter companies. Like mutual funds, REITs differ widely with respect to the safety and liquidity of their portfolio investments. Even if the statutory limitations were varied in some way to reflect portfolio composition, it is doubtful that the provisions could effectively distinguish between the many types of risk associated with various REIT portfolios; obviously, a unitary standard such as that imposed by section 18 would fail to distinguish between the diversity of risk situations represented by REIT portfolios.

Second, limitations on risk-taking through debt leverage restrictions have been criticized as forcing inefficient portfolio investments by disregarding leverage as a means of risk-optimization. Hence, under a body of principles generally referred to as "portfolio theory," ${ }^{271}$ given (1) a series of quantifiable measures of risk associated with a variety of investments, 272 and (2) the anticipated returns on each such investment, ${ }^{273}$ it is possible to derive a quotient reflecting the return per unit of risk associated with any given portfolio of investments. ${ }^{274}$ The portfolio that produces the highest return per unit of risk is the "optimum portfolio." 275 The risk associated with this portfolio may, in turn, be increased in the most efficient manner simply by increasing the debt leverage associated

271 For a concise explanation of the principles of portfolio theory and a critique of leverage limitations under these principles, see Cohen, The Suitability Rule and Economic Theory, 80 YALE L.J. 1604, 1607-17 (1971); Note, Regulating RiskTaking by Mutual Funds, 82 YaLe L.J. 1305, 1314-20 (1973).

272 Risk is measured as the amount of variation in all possible returns that an investment may produce. Cohen, supra note 271 , at 1608 .

273 The anticipated return is represented by the average of all possible returns on an investment, weighted according to probability of occurrence. Id.

274 In order to derive this figure, one subtracts the rate of return associated with risk-free investments (e.g., United States treasury bills) from the anticipated rate of return. The resulting figure, representing the return to the investor for taking risk, is then divided by the risk measure, yielding a quotient representing the return per unit of risk. Id.

275 It is "optimum" because any portfolio that yields a lower risk quotient would subject the investor (1) to a higher degree of risk for the same return; (2) the same degree of risk for a lower return; or (3) a higher degree of risk for a lower return. Assuming that the rational investor seeks to maximize return and minimize risk, he would consider any of these alternatives inferior to the "optimum" portfolio. 
with that portfolio.276 If, however, the portfolio may not be leveraged to increase risk, the only alternative is to alter the composition of portfolio securities in favor of higher risk investments. According to portfolio theory, this will, by definition, produce a portfolio that yields a lower rate of return per unit of risk, or a less than optimum portfolio. Although portfolio theory has principally been applied to portfolios consisting of debt and equity securities, it has equally valid theoretical application to the management of real estate portfolios. ${ }^{277}$

270 The proposition that an investor may maximize return by adjusting for risk through leverage is known as the "separation theorem." Simply stated, the separation theorem holds that any change in the composition of the optimum portfolio will result in a lower return per unit of risk. Any investor wishing to increase risk associated with the optimum portfolio should leverage the portfolio, because this will maintain the return per unit of risk that the optimal portfolio represents. Hence, if the unleveraged optimum portfolio returns 2 percent for each unit of risk, then borrowing doubles the risk, but doubles the possible return as well, thus maintaining the optimum return per unit of risk associated with the unleveraged optimum portfolio. See Cohen, supra note 271 , at 1609-11.

$2 \pi 7$ Assuming that it is possible to identify the range of possible returns on various types of real estate investments as well as the probability of each return, one could theoretically derive a series of quotients reflecting return per unit of risk, and thus identify the "optimum" real estate portfolio.

This theory relies on critical assumptions that may not hold true for REITs. Specifically, it assumes that one can determine with accuracy the possible returns and the respective probabilities associated with any real estate investment. The experience of REITs in this decade suggests that REIT managers in fact did not (and could not) accurately assess these factors. The history of real estate values since the early 1930s gave few lenders or developers cause to perceive any "downside" risk associated with real estate development. See e.g., P. Schurkm, ComMERcial Paper and the REIT INDUStry IN PERSpective 9-14 (1973). In fact, subsequent events demonstrated that the downside risk was substantial. More significantly, the prime rate in 1973-74 rose to unprecedented levels, a factor dictated by monetary policies that were largely beyond the REIT's ability to control or predict. Finally, REIT managers may have taken excessive risks by extending loans to meet competition from other REITs to maintain or increase earnings per share when the risk/return calculation dictated caution. Available statistical data are inconclusive on this point, e.g., Hines, Risks, Yields, Capitalization and Management Fees of Mortgage Trusts, 41 ApPRAISAI J. 484 (1973), although excessive industry competition and resultant imprudent lending policies have been emphasized as factors that explain the explosive portfolio growth. Kaplow, Leaders Blast Irresponsible Overbuilding; Many Go Condo, APARTMEnT Construction News, June 1972, at 1, col. 3; N.Y. Times, Nov. 19, 1971, $\$ 2$, at 63, col. 7 .

These problems notwithstanding, portfolio theory cannot be discounted in evaluating the efficacy of risk regulation through restrictions on leverage. The confluence of unpredictable events that precipitated the downturn in the real estate sector in 1974 were arguably atypical; in less volatile economic circumstances, risk and return should be more predictable, and hence more adaptable to the principles of portfolio theory. At the very least, it can be expected that consideration of the "downside" risk will more often become a meaningful factor in real estate investment decisions. Moreover, the competitive atmosphere that fostered excessive portfolio expansion and risk-taking has been tempered significantly since the REIT downturn. Thus, REITs and financial institutions lending to REITs may act more rationally in future years in evaluating risk factors relative to rates of return than was the case earlier in the decade. 
Finally, although REITs and mutual funds are both pooled asset enterprises that invest in portfolios that require similar analysis of risk considerations, their economic roles as financial intermediaries differ significantly. Institutional investors, including banks and mutual funds, typically effect transactions in the secondary capital markets ${ }^{278}$ by purchasing and selling outstanding debt and equity securities. Although such institutions participate in the purchase of primary debt and equity securities, their participation in secondary equity markets greatly exceeds their activity as purchasers of primary offerings. ${ }^{279}$ REITs, by contrast, function principally as primary financial intermediaries, channeling funds from investors and financial institutions into new mortgages and equity investments. ${ }^{280}$ Indeed, legislation granting tax-exempt status to qualified REITs was originally enacted, in part, to stimulate primary real estate investments. ${ }^{281}$ The imposition of leveraging restrictions on REITs would undoubtedly curtail their ability to discharge this vital intermediary function by restricting access to major financial sources, including banks and the commercial paper market.

\section{Recommendation}

The foregoing discussion suggests that limitations on debt leveraging comparable to those imposed on investment companies may be an inefficient and undesirable approach to the regulation of excessive risk assumption by REITs. The solution lies in implementing less limiting approaches to the over-leveraging problem that are tailored to the distinctive problems of the REIT.

As previously stated, ${ }^{282}$ excessive leverage may be encouraged by advisory compensation agreements that yield higher fees as portfolio size increases. Legislation imposing a fiduciary standard on

278 Sales of newly-issued securities (primary sales) are distinguished from sales of outstanding securities (secondary sales) by the fact that the proceeds of primary sales are at the disposal of the issuing corporations. Secondary sales, by contrast, involve sales of outstanding securities among investors, with no immediate impact on the funds available to the issuing corporation. InstrTutronal INVESTOR STUDY, supra note 225, at 2336.

279 Hence, of 1,684 registered public offerings between 1967 and 1970, institutional purchases accounted for 25 percent of the total; by contrast, during this same period, it is estimated that institutional activity on the New York Stock Exchange, the largest secondary equity market, accounted for more than 50 percent of all trading activity. INSTITUTrONAL INVESTOR STUDY, supra note 225, at 2333. The study also found that new issues constitute a relatively small portion of institutional portfolios. Id. 2323.

280 REIT FACTBOoK, supra note 1, at 6.

281 See note 6 supra.

282 See notes 168 \& 169 supra \& accompanying text. 
trustees and REIT advisers with respect to advisory fees, including a requirement that certain categories of information be disclosed to and considered by the nonaffiliated trustees, would significantly temper the present incentives to increase portfolio size merely to increase advisory fees. If the REIT trustees penalize substandard earnings performance by demanding a reduced level of advisory compensation, the adviser will have a strong incentive to avoid excessive leveraging. ${ }^{283}$

More stringent controls on loans to REITs from affiliated financial institutions could also limit incentives to finance investments through excessive leverage. Section 23A of the Federal Reserve Act ${ }^{284}$ imposes a limitation on loans by member banks to any one affiliate of ten percent of the capital stock and surplus of the member, and an aggregate limitation of twenty percent with respect to loans to all affiliates. The Federal Reserve Board has taken the position that the section 23A limitations do not apply to loan transactions between a REIT that is advised by a member bank or its affiliate and the member bank. ${ }^{285}$ However, given the objective of section 23A, the reach of the statute should be extended to restrict loans between a bank and a REIT sponsored by the bank.

Although the legislative history of section $23 \mathrm{~A}$ is scanty, it is clear that its primary purpose was to avoid exposing bank assets to undue risk by committing them to the support of bank affiliates. ${ }^{286}$ Implicit in the provision is a determination that loans to affiliates involve potential conflicts of interest that create incentives to extend loans that might not otherwise be extended. As discussed above, similar artificial incentives to extend loans are characteristic of the credit relationships between banks and bank-sponsored REITs, whether or not the REIT is technically an "affiliate" of the bank.2st In recognition of this fact, recently-introduced federal legislation would restructure section $23 \mathrm{~A}$ to bring bank-sponsored REITs within the definition of "affiliate," and thereby impose limitations on the aforementioned loan transactions. ${ }^{288}$ Although the legisla-

283 See text accompanying note 29 supra.

28412 U.S.C. $\$ 371$ (c) (1976).

285 P. Heller, Handbook of Federal Bank Holding Company Law 158 n.5 (1976); REIT Hearings, supra note 18, at 123-24 (statement of $\mathrm{R}$. Schotland).

286 See P. HELLER, supra note 285 , at $160 \mathrm{nn} \cdot 10-11$.

287 See notes 250-54 supra \& accompanying text.

288 Banking Affliates Act, S. 2810, 95th Cong., 2d Sess. (1978). The bill provides, in relevant part:

(2) Definitions. 
tion focuses on the protection of bank assets, the limitations on excessive debt financing of REITs by their sponsor banks should benefit the REITs as well as the banks.

The proposed amendment's limitations are not as likely to affect adversely investment in primary real estate markets as those of section 18 of the Investment Company Act. Unlike the Investment Company Act approach, a revised section 23A would not limit debt financing by the imposition of asset coverage requirements; it simply requires a bank-sponsored REIT to seek out other sources of financing when its limits have been exceeded. Such a limited incursion on REIT investment prerogatives is a cheap price to pay for an effective limitation on debt leverage in bank-sponsored REITs.

REITs and their institutional sponsors that are engaged in parallel business activities should also be subject to more stringent controls than are common management personnel. As previously suggested, any regulatory legislation directed at REITs should require a minimum number of nonaffiliated trustees on a REIT's board of trustees. ${ }^{289}$ Under the proposed definition, no individual could qualify as a nonaffiliated trustee if he was employed by, or was a substantial shareholder in, the investment adviser or any affiliated person of the investment adviser. With respect to those REITs that are sponsored or advised by financial institutions who engage in parallel business activities, it would be appropriate to require a

(a) The term "affliate" with respect to a member bank means:

(iv) any company, including a real estate investment trust, that is sponsored and advised on a contractual basis by the member bank or any subsidiary or affiliate of the member bank.

In recommending the inclusion of bank sponsored REITS as affiliates for purposes of the restrictions under $\$ 23 \mathrm{~A}$, the Federal Reserve Board voiced a number of concerns:

Such an extension of the statute recognizes that a bank may try to rescue a financially troubled organization that is sponsored and advised by the bank or its subsidiary or its affiliate in order to (1) prevent any damage to the reputation of the bank or its affiliate, or (2) forestall any lawsuits alleging that the sponsored organization received "bad advice" from the bank or its affliate. To the extent that advisory service revenues are related to the size of the organization that is sponsored and advised, a bank may also lend to the organization at preferential terms in order to increase the size of the organization, thus boosting the advisory service revenues received by the bank or its affiliate. In such situations, the Board believes the transactions would not be at "arm's-length" and, therefore, should be subject to the limitations of Section 23A.

Letter from Arthur F. Burns to William Proxmire, and attachments (Mar. 7, 1978) at 23-24 (footnote omitted) (on file with the University of Pennsylvania Law Review).

289 See notes 139 \& 140 supra \& accompanying text. 
greater percentage of nonaffiliated trustees on that REIT's board than on the boards of those REITs that are not sponsored or advised by such entities.

In summary, the REIT's role as a financial intermediary in primary real estate markets mandates a less restrictive regulatory approach to the problem of excessive risk-taking than that embodied in the Investment Company Act. The imposition of asset coverage requirements on REITs would unduly jeopardize their ability to stimulate investment in an area of the economy that is only now recovering from a devastating market collapse. The problems of excessive risk-taking and ill-conceived advisory compensation plans are inextricably related. If substandard earnings performance becomes a significant consideration in the setting of advisory compensation, a major incentive towards excessive leverage will be eliminated. In addition to this general approach, the special efforts outlined above are justified to regulate loan transactions between REITs and affiliated financial institutions.

\section{Conclusion}

As a financial intermediary, the REIT has been a highly significant force in channeling investment funds into the real estate sector. It has provided real estate investment opportunities that would otherwise have been unavailable to the small investor, and, perhaps more significantly, has provided an important source of risk capital to real estate entrepreneurs.

In the four years since the real estate collapse of 1974-75, the REITs that have managed to avoid bankruptcy have made significant recoveries. Rising real estate prices coupled with significant reorganizations in capital structure and portfolio composition have given many of the surviving trusts an opportunity to become significant forces in real estate investment once again. ${ }^{290}$ The potential importance and value of the REIT as a financial intermediary, as well as the possibility that REITs will indeed reassume a dominant role in real estate lending and development, highlight and reinforce the need for imposition of appropriate regulatory controls.

290 See, e.g., Campbell, REITs Are Shifting from Dogs to Darlings as Realty Markets Rebound from Recession, 19 Nat. REAL Estate Investon 57 (1977); Carberry, Improved Picture for Some REITs Prompts Analysts to Look at Speculative Investments, Wall St. J., Aug. 29, 1977, at 23, col. 3; Drob, Will Fortune Smile Again on Real Estate Investment Trusts?, 44 APpraIsal J. 450 (1976); Rudnitsky, Speculating in White Elephants, ForBes, Dec. 1, 1977, at 79. 
At the time of the passage of the Investment Company Act, mutual funds were a "relatively unimportant" part of the financial structure of this country. ${ }^{291}$ History has demonstrated that the imposition of regulatory controls did not thwart the growth of investment companies. ${ }^{202}$ The Investment Company Act and the legislation proposed in this Article embody specific legal responses to the inherent problems of externally-managed financial entities. The lessons of abuse of the advisory position and of the inadequacy of existing regulation should not be lost. Regardless of the current state of the industry, potential REIT investors should be assured that their interests will not be sacrificed to those of the adviser or its affiliates. Indeed, renewed investor confidence resulting from appropriate regulatory safeguards may well foster substantial further growth within the REIT industry.

This Article has suggested that the Investment Company Act provides a useful starting point in the analysis of possible regulatory approaches to REITs. The structure of REITs and regulated investment companies is sufficiently similar to raise common regulatory concerns in the areas of conflicts of interest in external management, fee structures, and risk-taking. The parallels, however, are imperfect, suggesting that application of certain provisions of the Investment Company Act to REITs, particularly in the prohibitions of affiliated transactions and the outright limitation on debt leverage, may be inappropriate.

Given these factors, it is this author's conclusion that regulatory legislation directed at REITs should define the respective fiduciary roles of external management and the trustees of the REIT, with statutory guidelines specifying the factors to be disclosed to and considered by the trustees in the principal areas where conflicts of interest may arise. If appropriate enforcement power is vested in the SEC and if private causes of action are allowed, a stringent fiduciary standard should adequately serve to ensure that the REIT is managed prudently and in the undivided interest of the REIT shareholders. In addition, the imposition of restrictions on loans by banks to sponsored REITs should foster sounder capital structures by REITs, thus lessening the vulnerability of REITs and REIT lenders to cyclical downturns in the real estate sector. With time, of course, the foregoing approaches may prove inadequate, and strict prohibitions on affiliated transactions and debt

201 Wharton School of Commerce and Finance, A Study of Mutual Funds, H.R. REp. No. 2276, 87th Cong., 2d Sess. 1 (1962).

202 Public Polscx Implycatrons, supra note 145, at 2. 
leveraging similar to those imposed on regulated investment companies, or even limitations going beyond those contemplated by the Investment Company Act, may be required. As a first step, however, the approaches suggested herein constitute a reasonable approach to the regulation of REITs and REIT advisers and should go far to provide needed safeguards in an important economic sector. 


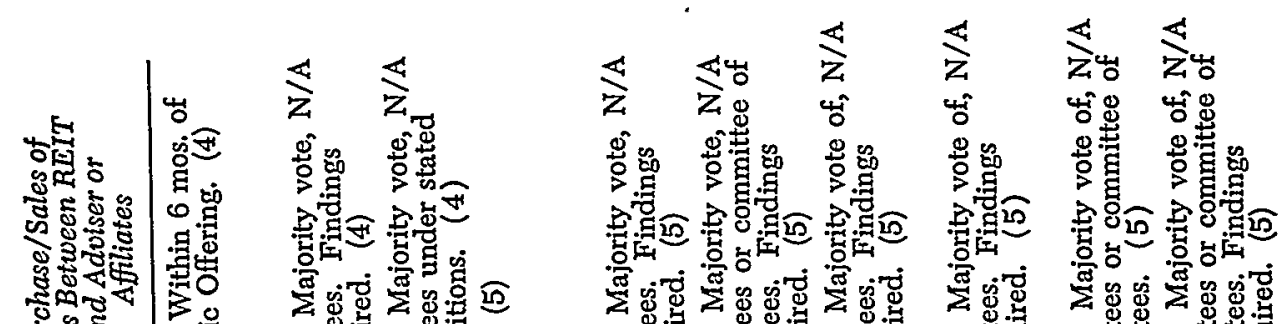

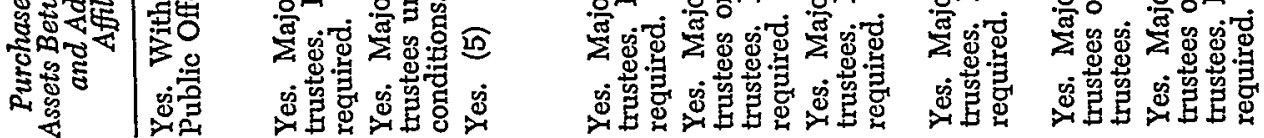

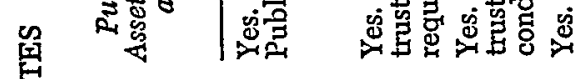

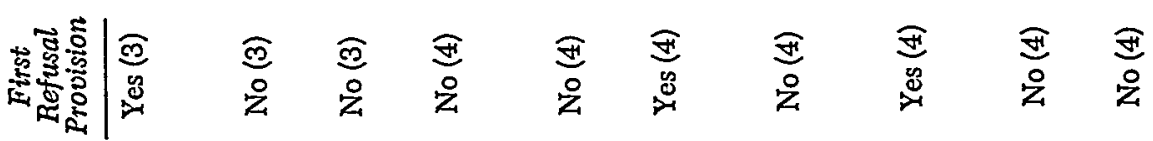

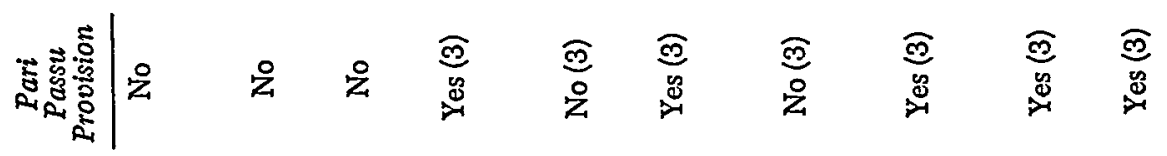

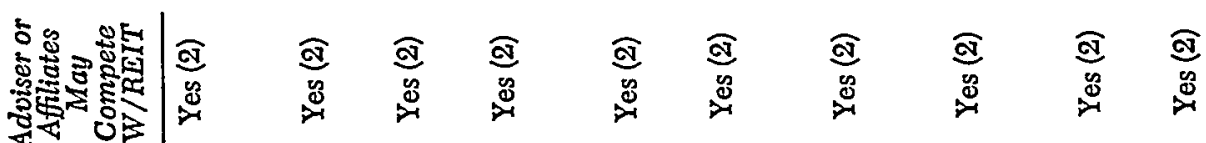
空 㝵 要

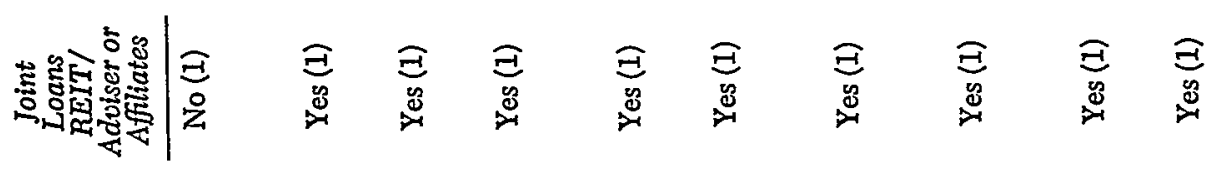
舁

瓷

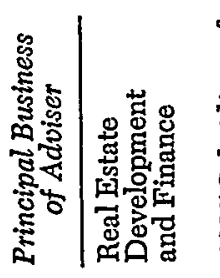

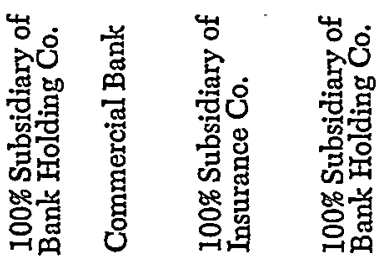
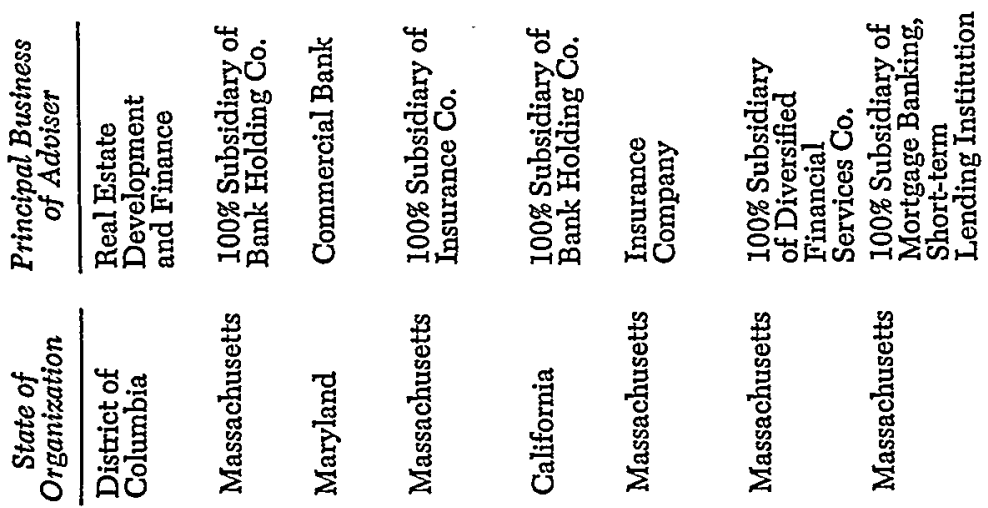

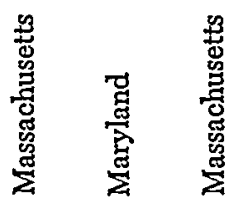

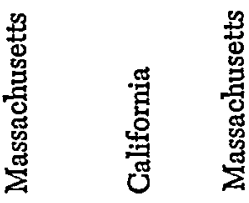

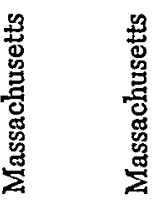

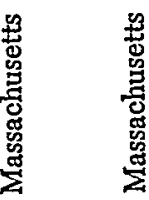

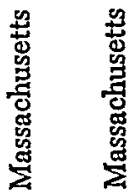




\section{NOTES TO APPENDIX A}

\section{B.F. Saul Real Estate Investment Trust}

(1) Prospectus dated March 12, 1974, at 45.

(2) "No express provision ... prohibits B.F. Saul Company (or its subsidiaries or affiliates, including the Advisor) or any officer, director or employee of B.F. Saul Company or the Advisor ... from performing investment advisory services for parties other than the Trust or from engaging in activities similar to or competitive with the investment operations of the Trust or from making real estate investments which might be suitable or desirable for the Trust." Id. 3.

(3) Id. 31 .

(4) Trust may acquire mortgages from B.F. Saul Company only during the first six months following the receipt of proceeds by the Trust from a public offering. Id. 45.

\section{Chase Manhattan Mortgage and Realty Investors}

(1) Registration Statement on Form S-1 dated May 27, 1977, at 50.

(2) Id.

(3) Id.

(4) Trustees must determine that such transactions are fair and reasonable to the Trust and are comparable to similar transactions with others not affiliated with the Trust. Id. 65.

\section{Citizens and Southern Realty Investors}

(I) Includes principally (a) joint loan transactions between Trust and Adviser (\$12.1 million principal amount, Dec. 31, 1977); and (b) loans to affliates of directors of the Adviser ( $\$ 41$ million during the period 1973-78). Registration Statement on Form S-11, dated April 28, 1978, at 76-77. Under the terms of a consent decree entered into between the Trust and the SEC on April 21, 1978, the Trust has agreed not to extend any new loans in which the Adviser has an interest or to issue any new commitments on loans made by the Adviser. Id. 73.

(2) Registration Statement on Form S-11 dated Apr. 20, 1978, at 68.

(3) Id.

(4) Trustees must determine that such transactions are fair and reasonable to the Trust and are on terms no less favorable than those prevailing in arms-length transactions involving persons not affiliated with the trust. Adviser (or affliate) must retain at least a $5 \%$ interest in any mortgage or realty interest sold to the Trust. Declaration of Trust, as amended, Apr. 27, 1977, at 13.

\section{Connecticut General Mortgage and Realty Investments}

(1) Includes principally joint loans by Trust and parent of adviser. As of March 31, 1977, outstanding loan participations between Trust and advisory parent were $\$ 237.1$ million, of which the Trust's participations totalled $\$ 119.7$ million. Trust reserves right to make loans to affiliates of adviser, although it "does not presently intend to enter into such transactions." Trust may purchase developed properties from real estate development subsidiary of adviser's parent. Annual Report on Form 10K, Year Ended Mar. 31, 1977, at 3 and Annual Report to Shareholders (attached), at 19 .

(2) Annual Report on Form 10K, Year Ended Mar. 31, 1977, at 7.

(3) "[The advisory agreement] provides that [the parent of the Adviser] will provide access to the advisor to review each mortgage and real estate opportunity presented to [the parent] and that [the parent] and the Trust each will be entitled to participate in such of those investment opportunities which it deems suitable." Registration Statement on Form S-11, dated May 19, 1971, at 22.

(4) $I d$.

(5) Trust will not purchase property from, sell property to, or make loans to the Adviser or any officer, director, or employee thereof. Trust may enter into such transactions with companies which are affiliated with Trustees, including Adviser's parent, if terms are fair and reasonable to Trust and on terms at least as favorable as in comparable transactions with nonaffiliated parties. Id.

\section{Continental Illinois Realty}

(1) Includes principally (a) issuance by the Trust of short term construction loan commitments on properties in which a "common control" affiliate had acquired equity interests (as of Sept. 1977, total purchase price of properties representing such interests was $\$ 66.9$ million), Registration Statement on Form S-11, dated Dec. 
27, 1972, at 32; (b) sale of participation by Trust to the parent of the advisory company of $\$ 61.2$ million; and (c) participation in certain construction loans by the Trust and the parent of the advisory company. Annual Report on Form 10K, Year Ending Mar. 31, 1977, at 45-46.

(2) Prospectus dated Aug. 30, 1974, at 4.

(3) Id.

(4) Id.

(5) Trustees are required to determine that such transactions are on terms which are fair and reasonable to the Trust and are at least as favorable to the Trust as similar arrangements for comparable transactions with others not having such affliation. Id.

Equitable Life Mortgage and Realty Investors

(1) As of Oct. 31, 1977, Trust's and Adviser's interests in joint loans were $\$ 409$ million and $\$ 189$ million, respectively. Annual Report on Form 10K, Year Ending Oct. 31, 1977, at 11-12.

(2) Prospectus dated Oct. 29, 1970, at 25-27 (incorporated by reference in Annual Report on Form 10K, Year Ending Oct. 31, 1977).

(3) Adviser must invest in each investment recommended to and taken by the Trust on terms equal to those of the Trust in an amount equal to $10 \%$ of the aggregate loan amount. Annual Report on Form 10K, Year Ending Oct. 31, 1977, at 11-12.

(4) Prospectus dated Oct. 29, 1970, at 25-27 (incorporated by reference in Annual Report on Form 10K, Year Ending Oct. 31, 1977).

(5) Trustees must determine transactions to be fair and reasonable and on terms no less favorable to the Trust than in comparable transactions with nonaffiliated persons. Prospectus dated Oct. 29, 1970, at 4 .

IDS Realty Trust

(1) "Most of the Trust's investments are made in the form of participations in loans made by the Adviser." Also includes (a) loans to a subsidiary of the Adviser and (b) investments in joint ventures in which wholly-owned subsidiaries of the Adviser have an interest. Registration Statement on Form S-11 dated Nov. 19, 1974 , at $39-40$.

(2) Id. 6.

(3) $I d$.

(4) Id.

(5) Trustees are required to determine that transaction is fair and reasonable to the Trust and, in cases involving acquisitions of mortgages, that the acquisition is on terms no less favorable than similar transactions, if any, known to the Trustees not involving affiliated parties. Id. at 32, 50-51.

Lomas and Nettleton Mortgage Investors

(1) Includes (a) participations in loans by Trust and parent of Adviser; (b) loans to entities affiliated with Trustees; and (3) long-term loan commitments by Adviser's parent on construction loans made by Trust. Preliminary Prospectus dated Oct. 27, 1972, at 6, 27-28, 32-33, 36-37.

(2) Id. 6.

(3) In specified instances, Trust may require Adviser or its parent to participate up to $15 \%$ of total of each loan recommended by the Adviser to the Trust (10\% if total participations of Adviser or its parent exceed \$15 million). Id. at 32-33.

(4) Id. 6.

(5) All transactions must be on terms fair and reasonable to the Trust and on terms at least as favorable as in transactions with nonaffliated persons. Id. 27.

MONY Mortgage Investors

(1) Includes principally joint loan transactions between Trust and Adviser. At May 31,1977 , the participations totalled $\$ 31.6$ million and $\$ 95.4$ million for the Adviser and Trust, respectively. Annual Report on Form 10K, Year Ending May 31, 1977, at 24.

(2) Prospectus dated Apr. 14, 1970, at 3-4.

(3) Adviser must participate at proportion of not less than 10 percent of all long-term first mortgage loans made by the Trust. Annual Report on Form 10K, Year Ending May 31, 1977, at 24. 
(4) Adviser is not required to present to the Trust any particular investment opportunity, even of the type which could be taken by the Trust. Trustees may, however, upon review of investments made by the Adviser, ask for right to participate and the Adviser, "to the extent it deems it consistent with obligations to its policyholders," may offer such participations. Prospectus dated Apr. 14, 1970, at 3-4. (5) Id. 4.

Northwestern Mutual Life Mortgage and Realty Investors

(1) Includes principally (a) joint loans by the Trust and Adviser and (b) loans by the Trust to entities in which the Adviser had an equity interest. At June 30, 1974, the participations (including unfunded commitments) totalled $\$ 150$ million and $\$ 326$ million for the Trust and the Adviser respectively. Prospectus dated Oct. 29,1974 , at $49-50$.

(2) $I d .7-8,47-48$.

(3) Trust may participate up to $10 \%$ in any loan accepted by the Adviser or its affliates "to the extent [the Adviser] deems it consistent with its obligations to its policyholders." Id.

(4) Id.

(5) Trustees must determine that the transactions are fair and reasonable to the Trust and on terms no less favorable than those obtainable in comparable transactions with nonaffiliated persons. Id. 61-62. 
APPENDIX $B$

Nonadvisory Compensation Received by Advisers or AfFiliates of Advisers

Name

B.F. Saul Real Estate Investment Trust

Chase Manhattan Mortgage and Realty Trust

Connecticut General Mortgage Realty Investments

Continental Illinois Realty

Citizens and Southern Realty Investors

Equitable Life Mortgage \& Realty Investors

IDS Realty Trust

Lomas \& Nettleton Mortgage Investors

MONY Mortgage Investors

Northwestern Mutual Life Mortgage \& Realty Investors
Type

Property Management (1)

None Indicated

Loan Servicing (2)

None Indicated

Loan Servicing;

Transfer Agent;

Auditing (3)

None Indicated

Loan Servicing;

Underwriting;

Registrar Fees;

Brokerage From Third

Parties (4)

Loan Servicing (5)

Loan Servicing (6)

Commercial Paper

Endorsement

None Indicated
Amount

$\$ 1.2$ million (yr. ending Sept. 30, 1977)

$\$ 471,000$ (yr. ending Mar. 31, 1977)

$\$ 38,000$ ( 9 mos. ending Jun. 30, 1977)

$\$ 6$ million (underwriting fees by IDS); $\$ 417,000$ servicing fees; $\$ 1.9$ million brokerage fees from third parties (yr. ended Jan. 31, 1974)

Not Indicated

$\$ 39,622$ servicing fees; $\$ 20,633$ endorsement fees (yr. ending May 31, 1977)

(1) Annual Report on Form 10-K, Year Ended Sept. 30, 1977, at F-18.

(2) Annual Report on Form 10-K, Year Ended Mar. 31, 1977, at 19 (attached Annual Report to Shareholders).

(3) Annual Report on Form 10-K, Year Ended Sept. 30, 1977, at 35.

(4) Registration Statement on Form S-11, dated Nov. 19, 1974, at 6, 37-40.

(5) Preliminary Prospectus dated Oct. 27, 1972, at 37-38. Adviser and/or parent may also receive fees from Trust or third parties for processing loan disbursements, property management, insurance, and handling escrows, reconveyances and foreclosures. Id. 36.

(6) Annual Report on Form 10-K, Year Ended May 31, 1977, at 20, 25. 


\section{APPENDIX C}

\section{LMMTtations ON LEVERAGE}

\section{Name}

B.F. Saul Real Estate Investment Trust

Chase Manhattan Mortgage and Realty Trust

Connecticut General Mortgage

\& Realty Investments

Continental Illinois Realty

Citizens and Southern Realty Investors

Equitable Life Mortgage and Realty Investors

\section{IDS Realty Trust}

Lomas \& Nettleton Mortgage Investors MONY Mortgage Investors

Northwestern Mutual Life Mortgage and Realty Investors

\section{Limitation \\ None (1) \\ None Indicated}

300\% of Net Assets (Excluding

Commercial Paper and Nonrecourse Indebtedness) (2)

None (3)

None Indicated

$300 \%$ of Net Assets on Prime Commercial Paper $10 \%$ of Total Assets on

Nonrecourse Debt $200 \%$ of Net Assets on Government-Related Debts $300 \%$ of Net Assets on All Other Debt (4)

$800 \%$ of Net Assets (5) $500 \%$ of Net Assets (6) $400 \%$ of Net Assets (7) $500 \%$ of Net Assets (8)

(1) Prospectus dated Mar. 12, 1976, at 17.

(2) Registration Statement on Form S-11, dated May 19, 1971, at 15.

(3) Registration Statement on Form S-11, dated Dec. 12, 1972, at 11.

(4) Prospectus dated Oct. 29, 1970, at 17-18.

(5) Registration Statement on Form S-11, dated Nov. 19, 1974, at 27.

(6) Prospectus dated Mar. 14, 1972, at 12.

(7) Prospectus dated Apr. 14, 1970, at 36.

(8) Prospectus dated Oct. 29, 1974, at 38. 